\title{
Potential biomarkers of immune protection in human leishmaniasis
}

\author{
Mahmoud Nateghi Rostami ${ }^{1} \cdot$ Ali Khamesipour $^{2}$ (D)
}

Received: 12 February 2020 / Accepted: 22 March 2021 / Published online: 2 May 2021

(c) The Author(s), under exclusive licence to Springer-Verlag GmbH Germany, part of Springer Nature 2021

\begin{abstract}
Leishmaniasis is a vector-borne neglected tropical disease endemic in over 100 countries around the world. Available control measures are not always successful, therapeutic options are limited, and there is no vaccine available against human leishmaniasis, although several candidate antigens have been evaluated over the last decades. Plenty of studies have aimed to evaluate the immune response development and a diverse range of host immune factors have been described to be associated with protection or disease progression in leishmaniasis; however, to date, no comprehensive biomarker(s) have been identified as surrogate marker of protection or exacerbation, and lack of enough information remains a barrier for vaccine development. Most of the current understanding of the role of different markers of immune response in leishmaniasis has been collected from experimental animal models. Although the data generated from the animal models are crucial, it might not always be extrapolated to humans. Here, we briefly review the events during Leishmania invasion of host cells and the immune responses induced against Leishmania in animal models and humans and their potential role as a biomarker of protection against human leishmaniasis.
\end{abstract}

Keywords Leishmaniasis $\cdot$ Immunology $\cdot$ Biomarkers $\cdot$ Protection $\cdot$ Vaccine $\cdot$ Macrophage

\section{Introduction}

Leishmaniasis is a vector-borne neglected tropical disease endemic in over 100 countries around the world. Clinical manifestations of the disease are mainly cutaneous (CL), mucocutaneous (MCL) and visceral (VL) and post kala-azar dermal (PKDL) leishmaniasis [1, 2]. The pathogenesis of leishmaniasis is influenced by elements from the triad of parasite-host-vector interplay. At least in murine model of leishmaniasis, the type of immune response generated upon infection with Leishmania plays a crucial role in the outcome of the disease either cure and protection or progression and even death. Although plenty of data concerning the factors involved in pathogenesis of Leishmania infection and the effector mechanisms of the host immune response

Edited by C. Bogdan.

Ali Khamesipour

Ali.khamesipour@gmail.com

1 Department of Parasitology, Pasteur Institute of Iran, Tehran, Iran

2 Center for Research and Training in Skin Diseases and Leprosy, Tehran University of Medical Sciences, 14155-6383 Tehran, Iran are collected in animal models and patients during the last decades, but yet the immune biomarkers of cure/protection or exacerbation in human leishmaniasis are not well defined.

It is well known that CL caused by natural infection or leishmanization induces strong protection against further CL lesion development, which justifies to develop vaccine against leishmaniasis [3]. Wealth of information which is accumulated over the past years on the biology of intracellular parasites, map of Leishmania genome, and numerous experimental studies on the immunology of leishmaniasis, supported search to develop an effective vaccine (reviewed in $[4,5])$. In the last decades, numerous Leishmania vaccine candidates have been introduced as vaccine candidate including whole live, attenuated, genetically modified, killed parasites, and subunits or fusion proteins, but only a few have been tested in clinical trials [4]. The absence of a vaccine against leishmaniasis is primarily attributed to the absence of clear understanding of correlates of protection [6]. Moreover, animal models of leishmaniasis do not always mimic human leishmaniasis [7], and extrapolating results of protection assays obtained with the experimental murine models to humans is doubtful. 


\section{Methods}

A literature search using the PubMed, Scopus and Google Scholar databases has been conducted for publications with full text or abstract in English language over the last 45 years. Relevant additional articles identified during review by authors were also included.

Search terms included were "Leishmania* AND (immune response OR immunology OR protection)" or "leishmaniasis AND biomarker". The initial search strategy identified more than 10,000 results. To limit search hits, other fields such as title [Ti], title abstract [Tiab], English [lang] and publication year [dp] were used which decreased the number of results to 7897 articles. Based on the title and the abstract, 523 articles including 46 review papers and 477 original papers were carefully analysed and finally 280 were cited.

\section{Macrophages and initiation of Leishmania infection}

Macrophages (M $\Phi)$ are known as the primary antigen presenting cells (APCs), other phagocytic cells including monocytes, dendritic cells and neutrophils are also recruited to the site of infection and play important roles (reviewed in [8]). It has been proposed that Leishmania parasites use neutrophil polymorphonuclear leukocytes (PMNs) as temporary host cells to silently enter macrophages without activation of defence mechanisms (Trojan horse hypothesis) [9]. Subsequently, macrophages phagocytose free parasites and apoptotic PMNs infected with Leishmania parasites and serve as the definitive host cells and permit parasite growth. However, macrophages are naturally responsible for killing of invading parasites by activation of effective microbicidal mechanisms (reviewed in [10]). The effective elimination of parasites by macrophages and development of protective immune response against Leishmania require involvement of dendritic cells (DCs) [10].

Leishmania parasites are able to engage different cell surface receptors including complement receptors [11, 12], fibronectin receptor [13], Toll-like receptors 2, 3 [14] and 4 [15] and mannose receptor [16] to enter into the host cells. The leishmanial membrane protease gp63 cleaves $\mathrm{C} 3 \mathrm{~b}$ attached to its surface, converts it to C3bi inactive form which binds to CR3 receptor, and mediate entry of opsonized promastigotes into macrophages. This strategy protects the parasites from lysis by complement activity [17].

Leishmania parasites are engulfed by macrophages and are eliminated by production of interferon gamma (IFN$\gamma)$, reactive oxygen species (ROS) and nitric oxide (NO) derivatives inside phagolysosome; however, intracellular amastigotes modulate various antimicrobial defense pathways and interfere with a number of critical macrophage functions to sustain and multiply inside the cell (reviewed in [18]). Macrophages successfully phagocytose Leishmania parasites, but the production of IL-12 is inhibited by the intracellular parasites [19]. It was shown that internalization of L. major through CR3 receptor, which is a mechanism of silent entry into macrophages, leads to blockade signaling cascade and synthesis of interleukin 12 (IL-12) [20, 21]. IL-12 is necessary for the killing of Leishmania parasites by macrophages, as it allows for upregulation of inducible nitric oxide synthase (iNOS or NOS2) and NO synthesis and subsequent parasite elimination [22, 23] by promoting the development of $\mathrm{CD} 4{ }^{+} \mathrm{T}$ cells and production of IFN- $\gamma$ (basic findings on the role of Th1/Th2 cytokines in reference [24]). Leishmania infection also leads to induction of other regulatory cytokines such as IL-10 and transforming growth factor $\beta$ (TGF- $\beta$ ) which interfere with macrophage effector functions in favor of parasite survival and disease progression [25].

\section{Macrophage: arginine metabolisms and NO production}

Among the most important players are arginine-derived metabolites which significantly influence the parasite survival in macrophage (reviewed in [26]). Polyamines are essential metabolites in trypanosomatid protozoa and play a role in the synthesis of thiol trypanothione. Polyamines are synthesized by a metabolic process involving arginase 1 enzyme (arg1) which catalyzes the hydrolysis of L-arginine to L-ornithine. Animal studies showed that induction of $\arg 1$ enzyme promotes Leishmania growth and dissemination in vivo, and induction of non-healing leishmaniasis [27]. In contrast, inhibition of arg1 activity is associated with limited pathology, the lower parasites burden and delays in disease outcome in BALB/c mice [28]. Spleen macrophages isolated from $L$. donovani-infected hamster showed low iNOS but high $\arg 1$ enzyme along with increased polyamine synthesis [29].

In human leishmaniasis, higher levels of arg1, TGF- $\beta$, ornithine decarboxylase (ODC), and prostaglandin E2 in plasma and higher expression of $\arg 1$ and ODC in lesion biopsies have been shown in L. amazonensis-infected patients with diffuse CL (DCL) compared with patients with localized CL (LCL), indicating a role for arg 1/polyamines in DCL development [30]. It was shown that the level of arg 1 activity is higher in blood PMNs of patients with chronic CL than that of acute CL, suggesting a possible role of arg1 in chronicity of CL lesions caused by L. major/l. tropica [31]. A high $\arg 1$ activity was shown in peripheral blood mononuclear cells (PBMCs) and plasma of VL and VL-HIV 
co-infected patients and as such an increase level of arg 1 is suggested as a marker of VL severity [32].

Polarising signals activate macrophages leading to their development into functionally distinct subsets which influence intracellular Leishmania survival and determine disease outcomes. Th1 type of cytokines particularly IFN- $\gamma$, induce classically activated (M1) macrophages which produce a significant amount of NO and initiate parasite killing. Classically activated macrophages may contain lower concentrations of arginine, as a result of NO production. In contrast, by activation of Th2 type of cytokines such as IL-4 and IL-13, alternatively activated macrophages (M2) are developed which characterized by increased expression of $\arg 1$ and polyamine biosynthesis, favouring amastigote growth in macrophages and disease progression [33, 34]. Genetic disruption of amastigote arginase resulted in reduction of parasite replication [35] and significantly attenuated infection in murine model [36], an indication of amastigotes reliance on de novo synthesis of polyamines.

Mononuclear cells produce two major anti-Leishmania components; ROS which is generated by respiratory burst during phagocytosis, and NO, which is produced by iNOS in response to IFN- $\gamma$ (reviewed in [37, 38]). T cells are the main source of IFN- $\gamma$ production, an initial macrophage activation through IFN- $\gamma$ is necessary for parasite killing through oxidative-burst mechanisms [39]. In addition to IFN- $\gamma$, there are a number of other inflammatory cytokines, such as IL-1, tumor necrosis factor (TNF), interferon alpha (IFN- $\alpha$ ), and interferon beta (IFN- $\beta$ ) which are also involved in macrophage activation and induction of iNOS expression and NO production (reviewed in [40]).

Production of ROS showed to be an important part of host cell immune response to induce anti-parasitic effector mechanisms, albeit the role of ROS in Leishmania infection control in murine model varies and depends on the parasite species and mouse strains. Unlike what observed in L. major infection, NADPH oxidase, which is required to generate ROS, showed no impact on the course of L. braziliensis infection in mouse model [41]. In human, however, production of ROS is shown to be an important part of control mechanisms of L. braziliensis infection [42].

Similarly, NO is an essential factor in control of Leishmania infection in mouse model, genetic deletion or functional inactivation of iNOS in L. major infected mice on a resistant background at early stage of infection, abolished IFN- $\gamma$ release by NK cells and increased TGF $\beta$ expression, resulted in a progressive parasite dissemination throughout the infected mouse. Furthermore, induction of iNOS was dependent on IFN $\alpha / \beta$ production $[43,44]$. The function of iNOS and NO in human leishmaniasis is less known, while production of ROS is shown to be involved in killing of $L$. braziliensis by human macrophages, NO alone was found not to be sufficient to control the infection of monocytes from CL patients in vitro [42]. It was reported that NO production is not traceable in supernatants of human macrophages infected with $L$. chagasi, but in vitro blockade of NO affected parasite growth in human macrophages [45]. iNOS gene expression in the lesions of CL patients due to L. braziliensis was comparable to that of normal skin [39]. However, anti-Leishmania activity is shown for iNOS in skin biopsies collected from American CL patients where the frequency of iNOS-positive cells had a reverse correlation with parasite burden in L. mexicana CL lesions and the most prominent expression of iNOS was seen in lesions with the lower number of parasites [46].

Briefly, infected macrophages through production of respiratory burst-mediated ROS derivatives and IFN- $\gamma$ mediated $\mathrm{NO}$ are involved in parasite killing. On the other hand, there is evidence showing a protective role for NO or ROS in human leishmaniasis which might be used as a basis for future investigations on the role of NO/iNOS in human and an application as a biomarker.

\section{Dendritic cells and interactions with Leishmania}

Macrophages and DCs are both professional APC, but in regard to Leishmania infection, they use different strategies for parasite uptake, internalization and antigen presentation. DCs preferentially uptake Leishmania amastigotes opsonized with IgG through surface Fc $\gamma R I$ or Fc $\gamma$ RIII receptors [47]. Although the phagocytosis capacity of DCs is not completely comparable with that of macrophages [48], but antigen presentation and IL-12 production by DC is critical in $\mathrm{CD} 4+\mathrm{Th} 1$ and $\mathrm{CD} 8+\mathrm{T}$ cells development to mediate protective immune response against Leishmania infection [22, 49], In contrast to L. major and $L$. donovani parasites which promote production of IL- 12 by murine DCs, infection with $L$. mexicana and L. amazonensis amastigotes failed to activate DCs or to induce IL-12 production $[50,51]$.

Several subtypes of DCs have been identified in both humans and mice that have distinct functions and molecular features (reviewed in [52]). Plasmacytoid DCs (pDCs) are considered resident DCs which specially produce type I interferon, and classical DCs (cDCs), mediate antigen processing and presentation to $\mathrm{T}$ cells [53]. cDCs express the integrin CD11c and MHC class II, cDCs can be further divided into two major subsets $\mathrm{cDC} 1 \mathrm{~s}$ and $\mathrm{cDC} 2 \mathrm{~s}$. A transcription factor Zbtb46 (BTBD4) was identified which specifically expresses by all cDCs in both human and mouse but not by pDCs, monocytes, and macrophages [54].

Langerhans cells (LCs) are seen in human skin epidermis and mucosal tissues similar to murine langerhans cells which are identified by the presence of a transmembrane lectin with mannose binding specificity called langerin. LCs are differ markedly from other migratory DCs in their ontogeny and 
may have a protective or suppressive function in skin pathology (reviewed in [55]).

During inflammation, monocytes recruit to the site of inflammation and differentiate into "inflammatory DCs" which present DC markers (CD11c and zbtb46) and DC functions [56].

During recent years, numerous mouse models for the specific depletion of DC subsets have been generated which are used for elucidating specific functions of DCs (reviewed in [57]). In one approach, mouse models are developed that express diphtheria toxin (DT) receptor (DTR) under the control of a cell type-specific promoter, and subsequent administration of DT mediates selective depletion of the DTRexpressing cells. DT disrupts protein translation by involving elongation factor 2 which eventually leads to cell death.

Several DTR mouse strains have been generated for depletion of specific DC subsets, such as Zbtb46-DTR strain for specific depletion of cDCs, Cd207-DTR strain for depletion of LCs as well as cDC1s in skin-draining LNs, Ly75DTR strain for depletion of CD205+ cDCs (the majority are $\mathrm{CD} 8 \alpha+\mathrm{cDC} 1 \mathrm{~s})$, Clec $9 a$-DTR BAC strain for depletion of cDC1s, Xcrl-DTRvenus and Karma strains for complete depletion of cDC1s, and Clec4a4-DTR strain that allows for ablation of cDC2s [57]. Similarly, several DTR mouse strains have been generated for depletion of pDCs, monocytes and macrophages, allowing functional study of specific cell subsets (reviewed in [58]).

In the early phase of murine Leishmania infection, three types of DCs including epidermal LCs, dermal DCs (dDC) and inflammatory DCs, are localized at the site of infection and mediate APC function. DCs take up parasites at the site of infection and then migrate to the dLN to present antigens to $\mathrm{T}$ lymphocytes, initiating an adaptive immune response [59], but there is a discrepancy about the extent to which each subset of DCs is involved in the immune response generation against Leishmania [60]. This discrepancy seems to be mainly due to differences in the parasite species, the dosage, and the route of administration [61]. A timing schedule is proposed in establishment of a protective immune response to L. major infection in murine model, in which dDCs and LCs play a role early in infection, but later the cells are replaced by inflammatory monocyte-derived DCs and lymph node-resident DCs (reviewed in [61]).

Another study showed that CD8alpha-Langerin-DCs migrate to dLNs to present antigens to specific T cells to induce protective immune response against $L$. major infection [62], later a functional dichotomy has been suggested for two subsets of dDCs, where Langerin-dDC population mediates a CD4+ T-cell response, but Langerin $+\mathrm{dDC}$ subset is involved in early priming of CD8+ T cells [63].

Experimental data indicate a suppressive role for skin LCs in low dose L. major infection by expansion of parasitespecific regulatory $\mathrm{T}$ cells, whereas both murine and human data suggest that dermal inflammatory DC is associated with enhanced induction of Th1 response and promoting protection [61, 64].

\section{Leishmania persistent infection and immune evasion mechanisms}

Leishmania parasite uses several immune evading strategies [65-67] which might need involvement of cell surface molecules, particularly gp63 and LPG [68]. Metacyclic Leishmania promastigotes avoid complement-mediated lysis via surface LPG by deactivation of the classical and alternative pathways [69].

Leishmania amastigotes inhibit the assembly of NADPH complex which generates ROS [70], and interfere with several phosphorylation signaling pathways of the cells [71-73]. Down-regulation of Toll-like receptors (TLR) and the Janus kinase (JAK)-signal transducer and activator of transcription (STAT) signaling pathways genes are suggested in NK cells from DCL patients caused by L. mexicana [74]. Similarly, $L$. donovani infected macrophages are defective in the ability to phosphorylate downstream molecules of JAK2/STAT1 signaling pathways including STAT-1, JAK1, and JAK2 in response to IFN- $\gamma[71,75]$.

It was shown that inhibition of PKC-dependent activity contributes to the survival of $L$. donovani inside the macrophages [76] and inhibition of a mitogen-activated protein kinase (MAP kinase) of host cells following Leishmania infection is confirmed by several studies [77, 78]. Induction of ceramide synthesis in $L$. donovani-infected murine macrophages mediate inactivation of ERK1/2 MAP kinases which results in inhibition of transcription factors AP-1 and NF- $\kappa$ B, NO generation, and a lower parasite burden [79].

Leishmania also activates various molecules that inhibit intracellular signaling cascades. An important negative regulatory molecule is PTP SHP-1 which is involved in limiting the activation of the JAK/STAT pathways following $L$. donovani infection [75]. Induction of SHP-1 is vital for inhibition of NO generation which occurs through the inactivation of JAK2 and ERK1/2, and transcription factors NF-kB and AP-1 [80]. Another survival strategy used by Leishmania parasites is detoxification of important antimicrobial molecules that are secreted into the phagolysosome including superoxide radicals and nitrite derivatives, such as peroxidoxins LcPxn1/2 [81] and a superoxide dismutase [82].

Within macrophages, Leishmania promastigotes transform into amastigotes and replicate continuously until causing cell death and rupture. Microbicidal mechanisms of macrophages later on infection eliminate the intracellular parasites through NO production [83]. The fate of Leishmania parasites within DC is less clear, in both human CL and murine Leishmania infection, parasites 
persistence has been reported [84-86], but the main host cells for long-term persistence is not clearly defined. In the lymph nodes of mouse after cure of $L$. major infection, both macrophages and dendritic cells which derived from the skin, showed to harbour viable parasites [84]. LCs containing parasite are also detected in the skin lesion infiltrate from L. major-infected mouse [87].

Bogdan et al. showed that fibroblasts are responsible for about $40 \%$ of the persisting parasites in the draining lymph nodes of mouse after healing of cutaneous lesion due to $L$. major infection. The infected fibroblasts did not eliminate the parasites comparable to the infected macrophages, thus fibroblasts are proposed as safe host cells for the parasites in latent infection [88].

Owing to limited capability of de novo synthesize, Leishmania amastigotes require essential nutritional elements, such as amino acids, purines, lipids, and other metabolites which must be available within the parasitophorous vacuole (PV) to support amastigotes growth (metabolic pathways reviewed in [89]). Upon phagocytosis, metacyclic promastigotes transform into amastigotes in the host cell where they encounter a limitation in the availability of several nutrients (reviewed in $[89,90]$ ). Leishmania parasites constitutively express genes involved in core pathways of carbon metabolism throughout the life cycle [91]. Oligosaccharides such as mannose and galactose are integrated into the structure of LPG [92] which play a significant role in survival of the parasites within phagolysosomes by involvement in macrophage oxidative responses [93]. Additionally, lipid bodies are organelles in the macrophage consist of neutral lipids mainly triacylglycerol and sterol esters which partially support parasite's nutrient requirements and are involved in phagosome maturation and production of eicosanoids molecules which regulate immunity by either promoting or modulating inflammatory responses [94].

On the other hand, parasite ferric iron reductase (LFR1), ferrous iron transporter (LIT1) and heme transporter (LHR1) contribute to provide iron sources for Leishmania parasites and as such these molecules are essential for Leishmania viability and intracellular survival [95]. Up regulation of iron exporters including natural resistanceassociated macrophage protein (NRAMP-1) and Ferroportin (Fpn-1) which restrict the availability of iron to the parasite are recently shown in monocytes isolated from PKDL patients [96]. A secretory peroxidase of $L$. donovani down regulates NRAMP1 expression in peritoneal macrophages and allows iron access to Leishmania inside PV [97] and another iron regulator, hepcidin, facilitates iron sequestration within macrophages by mediating cell surface degradation of the iron exporter ferroportin [98]. For more detailed survival factors see reference [99].

\section{Interleukin 12 (IL-12) production}

Leishmania induces IL-12 production at early hours of infection which leads to NK cell activation and IFN- $\gamma$ production [100, 101]. A central role is assumed for both IL-12 and IFN- $\gamma$ to drive CD4 + T-cell differentiation and subsequent induction of protective immune response to $L$. major infection in mouse [102]. In normally resistant mouse strains, in vivo neutralization of IL-12 results in inhibition of IFN- $\gamma$ production by NK cells in lymph nodes [101], IL-12 is also necessary for down-regulation of Th2 type responses during L. major infection in vivo [103]. Nevertheless, there is evidence showing that the early IFN-y production following L. major infection is IL-12 independent [104].

In vitro and ex vivo studies showed that IL-12 deficient mice from resistant strain mount a strong Th2 type response with a high level of IL-4 and a low level of IFN- $\gamma$ expressions and develop progressive uncontrolled lesions similar to genetically susceptible BALB/c mice [105]. The role of IL-12 in the development of protective CD4+T-cell-mediated immunity in Leishmania infection has been shown in several other studies through neutralization of IL-12 using monoclonal antibody or deletion of IL-12 gene in resistant mice strains $[106,107]$ or through rIL-12 treatment in susceptible mice strains [100, 108, 109]. These findings implicate that IL-12 is essential for the development of effective Th1 type of response in leishmaniasis [110].

As mentioned in the previous sections, L. major has the ability to block IL-12 production in macrophages [19, 111] and DCs remain the major source of IL-12 in Leishmania infection. IL- $1 \alpha$ acts in conjunction with IL-12 and promotes Th1 differentiation and prevents disease progression in $L$. major susceptible BALB/c mice [48, 112]. Experimental studies suggested that sustained IL-12 is required for the maintenance of Th1 response in Leishmania infection [106, 109, 113].

Although, IL-12 seems to be essential in the dichotomy of immune responses to L. major infection in susceptible $v s$. resistant mice strains [107, 110], the role of IL-12 in human leishmaniasis is not fully clear. PBMCs culture from CL patients of Old World indicates a higher level of IFN- $\gamma$ and IL-12 expression and a lower level of IL-4 and IL-10 expression in the healing compared to non-healing CL patients [114]. In contrast, in CL caused by L. mexicana, in situ expression of IL-12 mRNA was found to be higher in non-healing lesions coincide with high expression of IL-10, indicating that IL-12 alone could not induce lesion healing $[115,116]$. Unresponsiveness of T cells to IL-12 activation is associated with persistence of parasite and active lesion due to L. guyanensis [117].

IL-12 was initially used as an adjuvant with soluble Leishmania antigen (SLA) against L. major challenge in murine model [118], recombinant human IL-12 was used 
as adjuvant with alum plus heat-killed $L$. amazonensis antigen [119] or killed L. major in primate models [120] however, the use of rhIL-12 in human leishmaniasis has not been verified, mainly due to safety issues and significant toxicity explored during clinical trials on other diseases (reviewed in [121]).

Neutralization of IL-12, both at early or late stage of $L$. donovani infection caused increased parasite load, reduced IFN- $\gamma$, IL-4, TNF and iNOS production, resulting in inhibition of tissue granuloma formation in the liver of susceptible $\mathrm{BALB} / \mathrm{c}$ mice $[122,123]$. IL-12 is crucial for induction of IFN- $\gamma$ producing $\mathrm{T}$ cells and protective host responses in the liver. Although in experimental model of $L$. donovani infection, IL-12 has an anti-Leishmania activity even in the absence of IFN- $\gamma$, which appears to be dependent on TNF production [124]. DCs in the spleen are the critical source of early IL-12 production following $L$. donovani infection and activation of DCs is crucial for optimal induction of immunity in the liver during the early phase of VL infection [122, $125,126]$. Study on $L$. infantum infected mice demonstrated that myeloid DCs, TLR9, and IL-12 are functionally linked to the activation of NK cells to produce IFN- $\gamma$ [127].

In human VL, CD4+ T cells mediate a protective immune response by production of various cytokines and chemokines that contribute in granuloma formation and parasite killing, such as IL-2, IL-12, IFN- $\gamma$, TNF, lymphotoxin (LT) and granulocyte/macrophage colony-stimulating factor (GMCSF), which have been measured in serum samples [128, 129]. PBMCs from active VL patients failed to produce IL-12 or IFN- $\gamma$ in response to in vitro stimulation with $L$. donovani antigens, however, the addition of exogenous rhIL12 to PBMCs from the same patients resulted in the expansion of IFN- $\gamma$ production [130]. Similarly, addition of IL-12 to the PBMCs cultures from American VL patients restored cellular immune responses showed by proliferative response and IFN- $\gamma$ production [131].

\section{Cytokines of Th1/Th2 types}

It is well known that $L$. major infection in susceptible $\mathrm{BALB} / \mathrm{c}$ mice is associated with generation of Th2 response with a high level of IL-4, progression of the disease and death, whereas almost in all other strains of mice, resistance is associated with generation of Th1 type of response with production of high IFN- $\gamma$ level that induce healing lesion and protection against further lesion development [83, 132-134]. Although there are well established explanation in regard to immune response in murine model of leishmaniasis, but regardless of tremendous studies on Th1/Th2 cytokine responses (as reviewed in [135]), the mechanisms of cure and protection in human leishmaniasis is not well defined yet $[4,136]$.
In anthroponotic CL (ACL) caused by L. tropica, correlation of a high expression level of Th2 cytokines including IL-4 and IL-10 with antimonial unresponsiveness, and upregulation of Th1 cytokines including IL-1 $\beta$, IL-12 P40 and IFN- $\gamma$ genes with response to treatment is shown [137]. In New World, individuals cured from CL showed a significant increase in the frequency of cells expressing Th1-type cytotoxic production profile (IFN- $\gamma^{+} /$granzyme $\mathrm{B}^{+} /$perforin ${ }^{+}$) which is an indicative of imbalance toward a cytotoxic response [138]. In some clinical forms of human leishmaniasis such as American CL, non-healing ACL and PKDL a mixed Th1/Th2 response is seen in vitro and in situ [139-142]. Furthermore, it is well established that human VL displays a Th2 response at early stage of the disease which shifts toward a mixed Th1/Th2 patterns, with high levels of IFN- $\gamma$ as well as IL-4/IL-13 secretion [143-145].

Several studies have been completed over the last decades to explore the role of Th1/Th2 responses in human leishmaniasis [146-149] and phenotype of Th1/Th2 cells or their polarised cytokines in lesion, cell culture or plasma have been characterized in leishmaniasis patients [136, 150-154]. However, several Leishmania antigens predominantly stimulate Th1 responses in vitro, that are not necessarily associated with protection [155]. In some cases, antigens which are associated with an early Th2 response such as LeishmaniaActivated C-Kinase Antigen (LACK) or cysteine protease CPB2.8 are found to be protective if administered with an appropriate adjuvant [155-158].

\section{Interferon- $\boldsymbol{\gamma}$ (IFN- $\boldsymbol{\gamma})$}

At early stage of Leishmania infection, IFN- $\gamma$ participates in the control parasite growth and lesion development. IFN- $\gamma$ activates effector mechanisms/signaling pathways of macrophages to eliminate intracellular pathogens primarily through NO production. Characterization of immune response in CL patients shows an upregulation of IFN- $\gamma$ production around the lesions [114, 159-161] and production of a significant high level of IFN- $\gamma$ but a low level of IL-10 from T cells in culture after healing [147, 148, 162], indicating the possible involvement of IFN- $\gamma$ in healing process of CL lesions. In $L$. braziliensis infection a long-lasting Th1 response with elevated level of IFN- $\gamma$ and down regulation of IL-4 and IL-10 production is shown in vitro and in situ which is apparently associated with healing of the skin lesion(s) [140, 141, 163].

In our studies on CL patients, a role for both CD4 + and $\mathrm{CD} 8+\mathrm{T}$ lymphocytes as the main source of IFN- $\gamma$ production is shown $[151,152,164]$, but prior to the development of adaptive immune response, IFN- $\gamma$ is primarily produced by NK cells [165], the role for NK cells in innate immune response is shown in different forms of human leishmaniasis $[163,166]$ (reviewed in [167]). 
It should be noted that exacerbated Th1-cell-mediated immune response during $\mathrm{CL}$, accompanies with excessive secretion of pro-inflammatory cytokines including IFN- $\gamma$, could cause tissue damage and contribute to the lesion progress [168].

VL is associated with T-cell suppression, which is characterized by lack of proliferation and IFN- $\gamma$ production by PBMCs in response to Leishmania antigens in vitro [169, 170]. While it is assumed that this in vitro unresponsiveness of VL patients might be due to the defects in immune system, whole blood cells of active VL patients maintain the capacity to secrete significant levels of antigen specific IFN- $\gamma$ and IL-10 [171] and CD4+ T cells are found as the main source of IFN- $\gamma$ production [172]. Individuals cured of VL usually mount antigen-specific IFN- $\gamma$ response in vitro and convert to leishmanin skin-test positive [173-175].

In experimental VL, IFN- $\gamma$ plays a critical role in the early immune response leading to control of parasite burden and eventual resolution of $L$. donovani infection which occurs within well-formed tissue granulomas in the liver of mice $[176,177]$. Treatment of $L$. donovani infected nude $\mathrm{BALB} / \mathrm{c}$ mice with IFN- $\gamma$ activated macrophages in mice but requires the presence of $\mathrm{T}$ cells for anti-Leishmania activity [178]. Experiments in mice showed that administration of IFN- $\gamma$ increased the efficacy of antimony chemotherapy [179] and IFN- $\gamma$ is used as an adjunct therapy for severe or refractory cases of VL [180].

IFN- $\gamma$ is a key cytokine of the immune system that involves in regulation of various cellular events through transcriptional control over different genes [181]. Up-regulation of class I and class II MHC expression [182], activation of microbicidal mechanisms including induction of the NADPH-dependent oxidase system, priming NO production, tryptophan depletion, up-regulation of lysosomal enzymes [182], augmenting surface expression of Fc $\gamma \mathrm{RI}$ on mononuclear phagocytes, thereby promoting antibody-dependent cell-mediated cytotoxicity, and stimulation of complementmediated phagocytosis are among the most important functions of IFN- $\gamma$.

In addition, IFN- $\gamma$ orchestrates the trafficking of immune cells to the sites of inflammation through regulating the expression of adhesion molecules (e.g., ICAM-1, VCAM1) and chemokines (e.g., IP-10, MCP-1, MIG, MIP-1/, RANTES) [182]. Also, IFN- $\gamma$ synergizes or antagonizes the effects of many cytokines through involvement in the cell signaling pathways. IFN- $\gamma$ exerts its effector anti-microbial functions in macrophages through inducible transcription factor Stat 1 [183], a cytosolic latent transcription factor that participate in regulation of target genes and transmit the immunological effects of IFN- $\gamma$ [184]. Stat1 induces expression of iNOS and cytokines such as IL-12, TNF, and IL1 $\beta$. Findings from $L$. major infection in resistant C57BL/6 mice lacking the Stat 1 gene demonstrated that Stat1-mediated
IFN- $\gamma$ induction is indispensable for the development of protective immunity against Leishmania infection [185]. Furthermore, a novel function of constitutive Stat 1 in modulation of phagosomal acidification is shown, which contributes in intracellular Leishmania growth in macrophage [186] (Table 1).

\section{Interleukin 4 (IL-4)/interleukin 13 (IL-13)}

Early evidence showed that expansion of IL-4 induces Th2 response in murine L. major infection and results in exacerbation of the lesion and generalization of the disease which eventually kills the animals $[187,188]$, neutralization of IL-4 using anti-IL-4 antibodies significantly but not completely attenuated the progression of infection in BALB/c mice $[189,190]$. IL-13 plays a role in chronicity of non-healing infection in mice [191]. Evidence provided from experiments on the IFN- $\gamma / \mathrm{IL}-4$ genetically engineered mice showed that IL-4 is a key player in susceptibility to L. major infection and magnitude of IL-4 response determines the severity of the disease in BALB/c mice [192]. Down-regulation of Th1 response through inhibition of IL-12 receptor (IL-12R $\beta 2$ ) expression is mediated by IL-4 in L. major [193-195], by IL-13 in L. amazonensis [191] or independent of IL-4/IL-13 in L. mexicana infection [196].

Despite these evidence, the role of IL-4 as a major factor which contributes in susceptibility is controversial. Although IL-4/IL-13 mediate susceptibility to Leishmania infection in murine model $[192,197]$ effector Th2 immune response is also evidenced in the absence of IL-4/IL-13 cytokines, where IL-4 -/- and IL-4R $\alpha$-/- mice were highly susceptible to L. major parasite [198]. These data suggested the possibility of involvement of other cytokines in the development of Th1/Th2 immune response during Leishmania infection. Furthermore, in contrast to the general consensus, a role for IL-4 cytokine in promoting a Th1 immune response has also been suggested [199]. Based on this report the time at which IL-4 is presented is determinative, during the initial activation of DCs, IL-4 induces production of IL-12 and promotes a Th1 response which is associated with resistance to $L$. major infection in susceptible BALB/c mice, but later during the period of $\mathrm{T}$ cell priming, IL-4 induces a Th2 response associated with progressive infection in resistant mice [199]. An experiment on the influence of recombinant IL-4/IFN- $\gamma$ on murine macrophage showed that IL-4 synergizes with IFN- $\gamma$ to activate macrophages and provides a strong stimulus to kill L. major amastigotes at low concentrations of IFN- $\gamma[200]$.

In human leishmaniasis, usually IL-4 level is negligible and hard to measure on culture supernatant of stimulated PBMCs in vitro [201, 202]. It was shown that in chronic and destructive MCL a mix Th1/Th2 type cytokines exist, with prominent upregulation of IL-4 mRNA expression in 


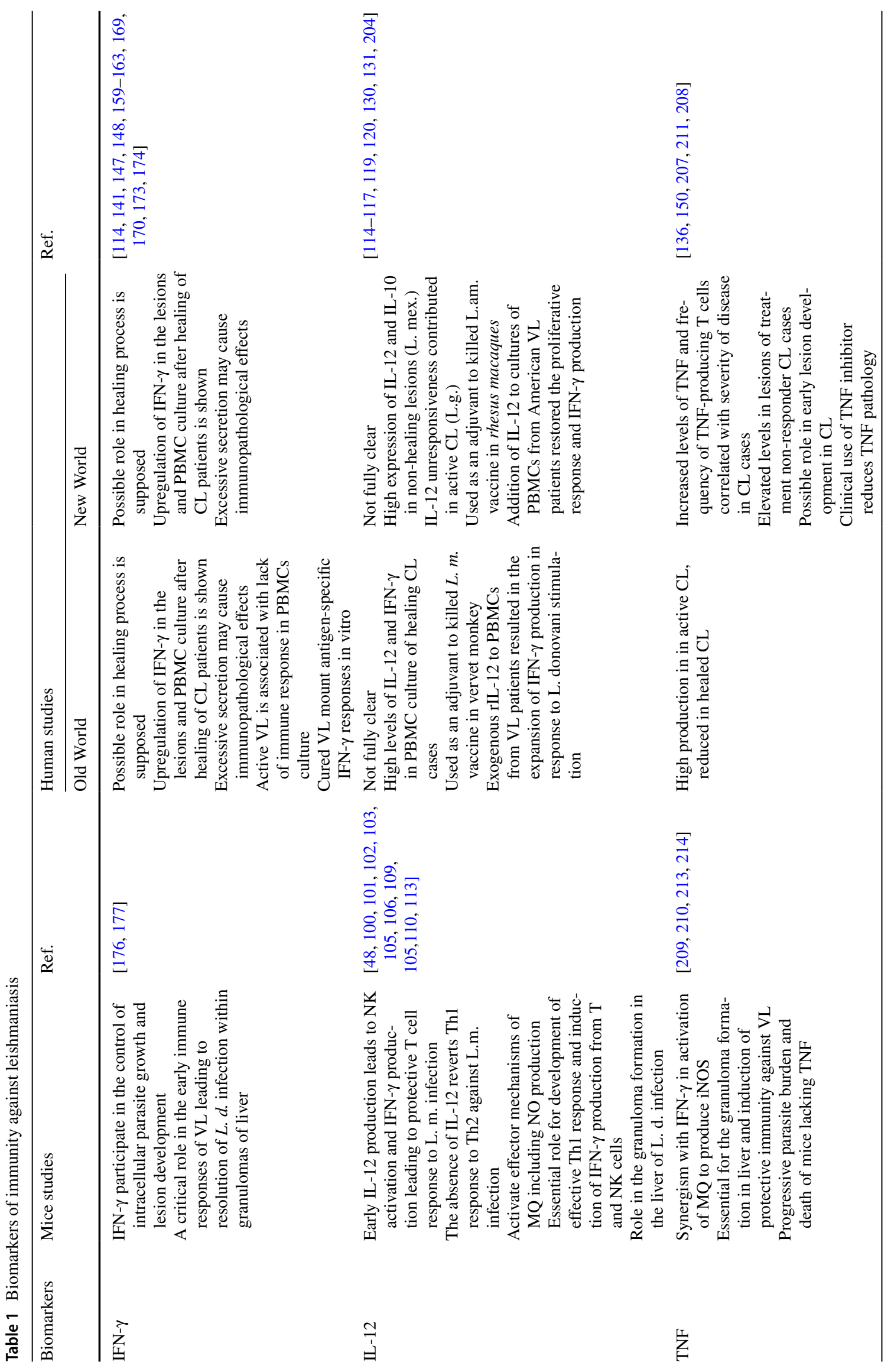




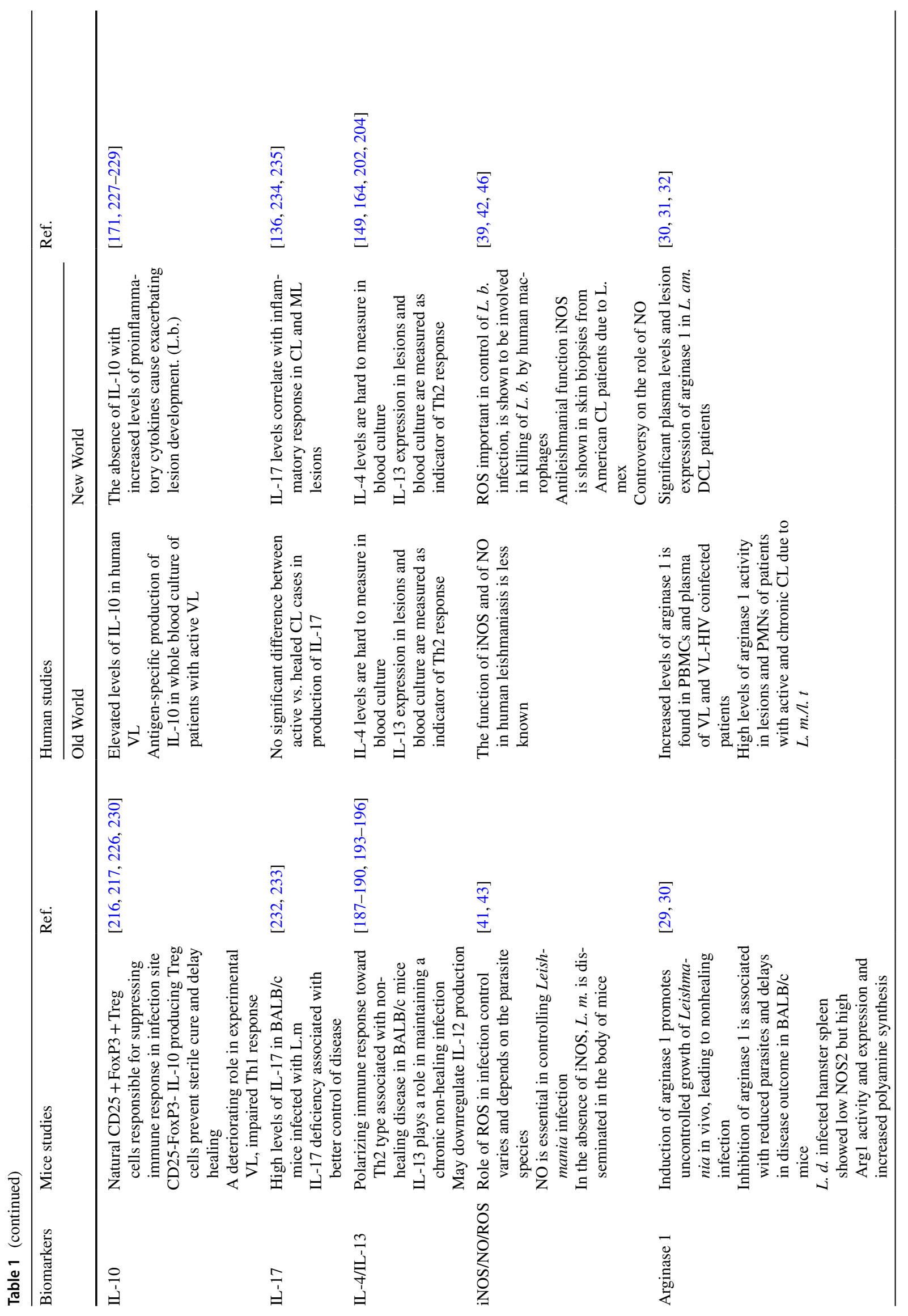




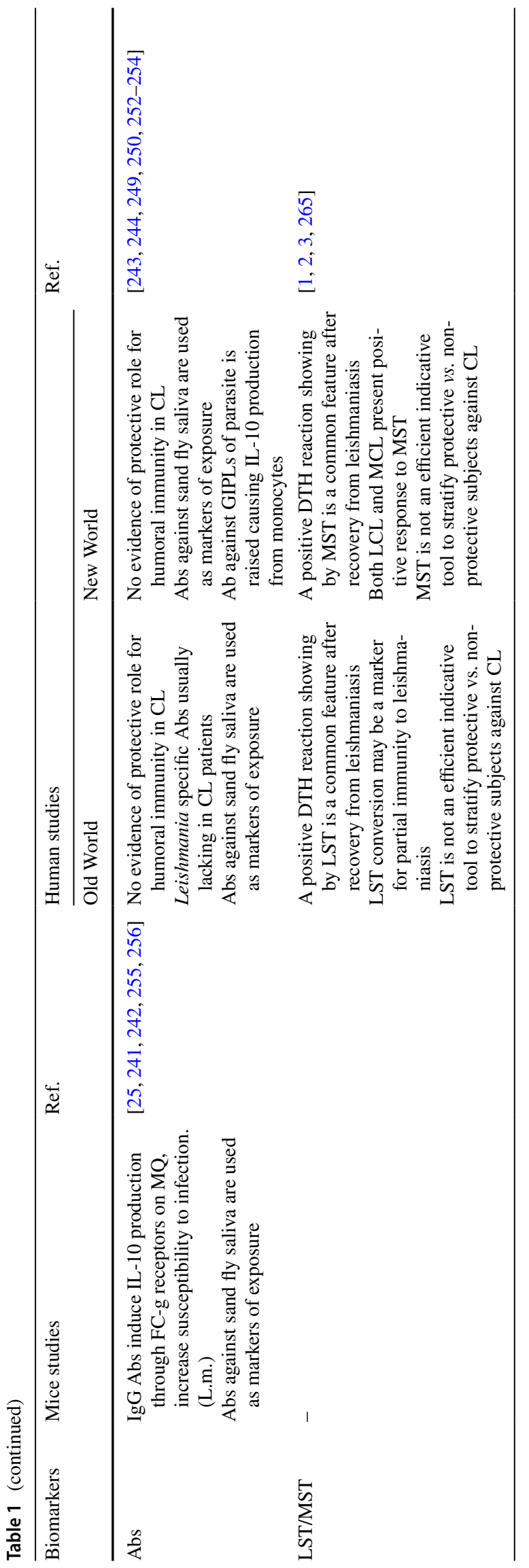

the lesions [203]. In both Old World [149, 164] and New World [204] leishmaniasis, IL-13 production in the lesions and peripheral blood have been measured as an indicator of Th2 response.

\section{Tumor necrosis factor (TNF)}

Existing data on the role of TNF in human leishmaniasis development are controversial, but most of the reports implicate that unregulated production of TNF contributes to the clinical outcome of leishmaniasis at early stage of infection [205, 206]. In two sequential studies of Zoonotic CL (ZCL) caused by L. major, we have shown that the mean level of TNF in plasma and supernatant of stimulated cells in culture is significantly higher in active CL patients than in healthy volunteers and significantly reduces after treatment of the lesion(s) $[136,150]$. Similar reports from New World are exist showing elevated levels of TNF production in CL lesions of who are nonresponsive to antimonial treatment [207]. Investigation of the immune response of American CL patients revealed a significant upregulation of gene expression of TNF and IFN- $\gamma$ cytokines within $24 \mathrm{~h}$ of in vitro stimulation of the cells which shifted to a dominant IL-10 and IL-4 production after $48 \mathrm{~h}$ [208], showing a possible role for pro-inflammatory cytokines in early phases of CL lesion development.

IFN- $\gamma$ and TNF act synergistically in the activation of macrophages to produce iNOS/NO during murine Leishmania infection [209, 210]. In leishmaniasis, cytokine balance is important in T-cell homeostasis and maintenance of protective immunity and imbalanced cytokines might induce pathogenesis. TNF shows a reciprocal role in the outcome of human leishmaniasis and an increased level of TNF correlates with severity of the lesion [211].

In mice, TNF antagonizes alternative activation of macrophages and dendritic cells by IL- 4 and TNF has a restricting effect on arg 1 expression leading to the production of NO by iNOS and parasite control [212].

In experimental VL, TNF produced by Leishmania infected Kupffer cells is essential for the granuloma formation and induction of protective immunity in liver [213]. Parasite burden is progressively increased in mice lacking TNF which leads to death [214]. Therefore, TNF appears to be a critical cytokine in resolution of experimental visceral infection [215].

\section{Interleukin 10 (IL-10)}

Following resolution of Leishmania infection in mice, a population of IL- 10 producing $\mathrm{CD} 25^{+} \mathrm{Foxp}^{+}$Treg cells prevent sterile cure and establish a chronic infection, allowing memory generation for a long-lasting protection (reviewed in [216]). Similarly, a population of antigen-induced 
CD25-Foxp $3^{-}$regulatory $\mathrm{T}$ cells that produce IL-10 is expanded following Leishmania infection [217] which modulates immune response to control immunopathological effects leading to delay in lesion healing.

The deteriorating role of IL-10 is shown in IL-10 deficient $\mathrm{BALB} / \mathrm{c}$ mice which were able to control the progressive L. major infection with 1000 -fold lower parasite burden [25]. Function of IL-10 as an inhibitory cytokine is well described; in vitro, IL-10 inhibits antigen-specific T-cell proliferation and type 1 cytokine production $[218,219]$ and renders macrophages refractory to activation by IFN- $\gamma$ for intracellular killing [25, 220, 221]. Recombinant mouse IL-10 showed a potent suppressing effect on the ability of mouse peritoneal macrophages to release TNF, reactive oxygen intermediates (ROI) and to a lesser extent reactive nitrogen intermediates (RNI) [222]. In resistant C57BL/6 mice following Leishmania infection, a low number of parasites persist after the lesion resolved [223-225] and naturally occurring CD $25^{+}$Treg cells are shown to be the source of IL-10 which is responsible for down regulation of effector immune response and parasite persistence.

A deteriorating role of IL-10 in experimental VL is seen, in which IL-10 overexpressed mice showed an increased parasite replication and impaired Th1 type responses. Despite subsequent granuloma formation, infection persisted, and antimony-treatment failed [226].In human leishmaniasis due to $L$. braziliensis, when increased production of IFN- $\gamma$ and TNF coincides with the absence of IL-10 in situ, a strong inflammatory reaction is promoted leading to destructive lesion development especially in ML [227-229]. Elevated level of IL-10 has been frequently reported in clinical studies of human VL and seems to contribute in pathogenesis of VL [230]. IL-10 is the key immunosuppressive cytokine in VL patients which is hard to detect in cultures of PBMCs collected from VL patients [170], but antigen-driven production of IL-10 is observed in whole blood of patients with active disease [171].

\section{Interleukin 17 (IL-17) and interleukin 22 (IL-22)}

Th17 population homing in skin and mucosal sites, produce cytokines such as IL-17, IL-22 and IL-23. IL-17 and IL-22 which are involved in the rapid response to infections, both by recruiting neutrophils and inducing production of antimicrobial peptides [231].

High levels of IL-17 have been found in BALB/c mice following infection with $L$. major, and IL-17 deficiency is associated with control of the disease [232]. In mouse model of leishmaniasis, in the absence of IL-10 modulation, both IFN- $\gamma$ and IL-17 production levels are increased and cause more severe disease following high doses of $L$. major, which is reversed by neutralization of IL-17 [233]. IFN- $\gamma$ and IL-17 levels correlate with the inflammatory response in the skin of patients with CL and ML [234, 235] indicating possible involvement of Th17 population in pathogenesis. However, in our study on human leishmaniasis, no significant difference was seen between active and cured CL individuals in the production of IL-17 from stimulated PBMCs [136]. Furthermore, we found that the mean level of IL-22 production in plasma and in SLA stimulated PBMCs of active VL patients was significantly higher than healthy controls and was significantly decreased in the same patients after healing of VL due to $L$. infantum $[136,150]$. The results suggested that the level of IL-22 production is conversely related to VL cure. It is claimed that IL-17 and IL-22 may have a synergistic role with Th1 cytokines in protection against human VL due to L. donovani [236].

\section{Serum antibodies}

There are studies that conceive a deteriorating role for B cells in experimental models of leishmaniasis by producing antibodies [237, 238] or cytokines such as IL-10 [226, $239,240]$. Although antibody response is induced in leishmaniasis especially VL, but antibody response does not play any significant role in protection. There are studies which indicate that IgG antibodies may be crucial in suppressing the host immune response by generating a high IL-10 response. L. major amastigotes opsonized with host IgG antibodies may ligate $\mathrm{Fc} \gamma \mathrm{R}$ on murine macrophages to induce production of IL-10 [25]. In vivo studies found that $\mathrm{Fc}$-deficient mice infected with $L$. mexicana produce less IL-10 and are less susceptible to infection [241, 242]. In human or mouse infection with L. mexicana, antibodies are raised against surface glycoinositol phospholipids of the parasite which induce production of IL-10 from monocytes [243].

The role of antibodies is not completely clear, humoral immune response does not have a protective role in $\mathrm{CL}$ and antibody response in CL of Old World is very low and sometimes difficult to detect (Khamesipour A, unpublished data); therefore, antibody titration is not applicable as a marker of cure or protection (reviewed in [244]). Nevertheless, humoral immune responses have been measured as a diagnostic approach in New World CL [245] and high level of anti-Leishmania antibodies are seen in VL patients which is used as diagnostic tool [246, 247]. It is shown that upon recovery of kala-azar, different antibody titers decline [248].

It is shown that human or canine reservoirs that exposed to sand fly saliva induce a high antibody response which is used as marker of exposure in surveillance studies [249, 250], reviewed in [251]. The yellow proteins LJM11 and LJM17 from saliva of Lutzomyia longipalpis are recognized by sera from humans living in VL endemic areas and animal reservoirs [252, 253]. PpSP32 is the immunodominant target for the serum antibody raised in humans naturally exposed 
to Phlebotomus papatasi saliva [254]. The apyrases rSP01B and rSP01 and the yellow protein rSP03B from saliva of $P h$. perniciosus, a principal vector of $L$. infantum in the Mediterranean Basin, are promising markers of canine exposure $[255,256]$.

\section{Leishmanin (LST)/Montenegro (MST) skin test}

Delayed type hypersensitivity (DTH), is used to evaluate cell mediated immune response in a few diseases, Leishmanin (LST) or Montenegro (MST) skin test is a DTH test similar to Mantoux test which is in use since 1929. In 1990s, at Pasteur Institute of Iran with full support of TDR/WHO a standard leishmanin was produced under GMP condition, in the recent one, the same L. major which was applied to mass leishmanization of more than 2 million people, was used. Leishmania was harvested at early stationary phase, washed and were killed using thimerosal $(0.1 \%)$, then the parasites were washed and treated with thimerosal, the number of parasite adjusted to $1 \times 10^{7}$ Leishmania per $\mathrm{mL}$, aliquoted and then each batch goes through control measures including toxicity, potency etc. tests. About $0.1 \mathrm{~mL}$ of leishmanin is inoculated intradermally using fine needle into ventral forearm [257, 258]. LST is used in epidemiological studies and for investigation of past exposure and is almost the unique tool to evaluate efficacy of experimental vaccine efficacy [259]. Usually, a portion of the residents of endemic areas are leishmanin positive. In Iran, the percentage of recovered persons with LST-positive results ( $\geq 5 \mathrm{~mm}$ indurations) was 99\%, 94\%, and 70\% for areas with ZCL, ACL, and ZVL, respectively [260]. LST positivity is not an indication of protection, in studies completed in Iran, LST positive individuals are as sensitive as LST negatives in regard to develop CL lesion [261].

In New World, of healthy individuals without a history of CL living in endemic areas, $10-15 \%$ have a positive MST result $[262,163,263]$. Both LCL and MCL present positive response to MST, indicating a cell-mediated immunity against the parasite and MST is reported to be positive in more than $90 \%$ of American tegumentary leishmaniasis [264, 265].

In relation to various clinical forms, one evidence showed that most of the strongly positive responses are seen in lupoid, and most of the negative LSTs are seen in sporotrichoid type of CL [266].

\section{Concluding remarks}

Leishmaniasis, a neglected disease with strong links with poverty, has long been a major public health problem in many developing countries with high morbidity and mortality rates. It seems necessary to implement effective measures as diagnostics, prophylactics and therapeutics to control this infection [267]. Advances in the understanding of the biology of Leishmania have not yet been translated into the development of vaccine or new therapeutic measures. During recent years, large-scale genomic and proteomic analyses have allowed characterization of the network pathways involving in the pathogenesis of Leishmania parasite. Combining these data offers a more comprehensive body of information that could be used to identify specific biomarker(s) of immunity against leishmaniasis. The potential biomarker(s) would be used as new target for development of vaccine and/ or drug against leishmaniasis.

Most of our current understanding of the role of different markers of immune response in leishmaniasis has been obtained by works performed in experimental animal models. Although results from these studies provide important insights into Leishmania immunity, but cannot always be extrapolated to humans as there seem to be significant differences between human and murine immune response against Leishmania infection. Hence, limited numbers of biomarkers have been investigated and so far none of which could be used as a definitive out-standing surrogate of protection against human leishmaniasis.

Author contribution MNR performed the literature search and contributed to manuscript preparation, editing, and revisions. AK contributed to the manuscript preparation, editing and revisions.

\section{Declarations}

Conflict of interest The authors declare that they have no conflict of interest.

\section{References}

1. Mitja O, Marks M, Bertran L, Kollie K, Argaw D, Fahal AH, Fitzpatrick C, Fuller LC, Garcia Izquierdo B, Hay R, Ishii N, Johnson C, Lazarus JV, Meka A, Murdoch M, Ohene SA, Small P, Steer A, Tabah EN, Tiendrebeogo A, Waller L, Yotsu R, Walker SL, Asiedu K (2017) Integrated control and management of neglected tropical skin diseases. PLoS Negl Trop Dis 11(1):e0005136

2. Burza S, Croft SL, Boelaert M (2018) Leishmaniasis. Lancet 392(10151):951-970

3. Khamesipour A (2014) Therapeutic vaccines for leishmaniasis. Expert Opin Biol Ther 14(11):1641-1649

4. Khamesipour A, Rafati S, Davoudi N, Maboudi F, Modabber F (2006) Leishmaniasis vaccine candidates for development: a global overview. Indian J Med Res 123(3):423-438

5. Iborra S, Solana JC, Requena JM, Soto M (2018) Vaccine candidates against Leishmania under current research. Expert Rev Vaccines 17(4):323-334

6. Gannavaram S, Dey R, Avishek K, Selvapandiyan A, Salotra P, Nakhasi HL (2014) Biomarkers of safety and immune protection for genetically modified live attenuated Leishmania vaccines 
against visceral leishmaniasis - discovery and implications. Front Immunol 5:241

7. Loria-Cervera EN, Andrade-Narvaez FJ (2014) Animal models for the study of leishmaniasis immunology. Rev Inst Med Trop Sao Paulo 56(1):1-11

8. von Stebut E, Tenzer S (2018) Cutaneous leishmaniasis: distinct functions of dendritic cells and macrophages in the interaction of the host immune system with Leishmania major. Int J Med Microbiol 308(1):206-214

9. van Zandbergen G, Klinger M, Mueller A, Dannenberg S, Gebert A, Solbach W, Laskay T (2004) Cutting edge: neutrophil granulocyte serves as a vector for Leishmania entry into macrophages. J Immunol 173(11):6521-6525

10. Liu D, Uzonna JE (2012) The early interaction of Leishmania with macrophages and dendritic cells and its influence on the host immune response. Front Cell Infect Microbiol 2:83

11. Mosser DM, Edelson PJ (1985) The mouse macrophage receptor for C3bi (CR3) is a major mechanism in the phagocytosis of Leishmania promastigotes. J Immunol 135(4):2785-2789

12. Polando R, Dixit UG, Carter CR, Jones B, Whitcomb JP, Ballhorn W, Harintho M, Jerde CL, Wilson ME, McDowell MA (2013) The roles of complement receptor 3 and Fcgamma receptors during Leishmania phagosome maturation. J Leukoc Biol 93(6):921-932

13. Brittingham A, Chen G, McGwire BS, Chang KP, Mosser DM (1999) Interaction of Leishmania gp63 with cellular receptors for fibronectin. Infect Immun 67(9):4477-4484

14. Flandin JF, Chano F, Descoteaux A (2006) RNA interference reveals a role for TLR2 and TLR3 in the recognition of Leishmania donovani promastigotes by interferon-gamma-primed macrophages. Eur J Immunol 36(2):411-420

15. Kropf P, Freudenberg MA, Modolell M, Price HP, Herath S, Antoniazi S, Galanos C, Smith DF, Muller I (2004) Tolllike receptor 4 contributes to efficient control of infection with the protozoan parasite Leishmania major. Infect Immun 72(4):1920-1928

16. Blackwell JM (1985) Role of macrophage complement and lectin-like receptors in binding Leishmania parasites to host macrophages. Immunol Lett 11(3-4):227-232

17. Brittingham A, Mosser DM (1996) Exploitation of the complement system by Leishmania promastigotes. Parasitol Today 12(11):444-447

18. Stafford JL, Neumann NF, Belosevic M (2002) Macrophagemediated innate host defense against protozoan parasites. Crit Rev Microbiol 28(3):187-248

19. Carrera L, Gazzinelli RT, Badolato R, Hieny S, Muller W, Kuhn R, Sacks DL (1996) Leishmania promastigotes selectively inhibit interleukin 12 induction in bone marrow-derived macrophages from susceptible and resistant mice. J Exp Med 183(2):515-526

20. Piedrafita D, Proudfoot L, Nikolaev AV, Xu D, Sands W, Feng GJ, Thomas E, Brewer J, Ferguson MA, Alexander J, Liew FY (1999) Regulation of macrophage IL-12 synthesis by Leishmania phosphoglycans. Eur J Immunol 29(1):235-244

21. Ricardo-Carter C, Favila M, Polando RE, Cotton RN, Bogard Horner K, Condon D, Ballhorn W, Whitcomb JP, Yadav M, Geister RL, Schorey JS, McDowell MA (2013) Leishmania major inhibits IL-12 in macrophages by signalling through CR3 (CD11b/CD18) and down-regulation of ETS-mediated transcription. Parasite Immunol 35(12):409-420

22. Berberich C, Ramirez-Pineda JR, Hambrecht C, Alber G, Skeiky YA, Moll H (2003) Dendritic cell (DC)-based protection against an intracellular pathogen is dependent upon DC-derived IL-12 and can be induced by molecularly defined antigens. J Immunol 170(6):3171-3179

23. Ahuja SS, Reddick RL, Sato N, Montalbo E, Kostecki V, Zhao W, Dolan MJ, Melby PC, Ahuja SK (1999) Dendritic cell
(DC)-based anti-infective strategies: DCs engineered to secrete IL-12 are a potent vaccine in a murine model of an intracellular infection. J Immunol 163(7):3890-3897

24. Mosmann TR, Coffman RL (1989) TH1 and TH2 cells: different patterns of lymphokine secretion lead to different functional properties. Annu Rev Immunol 7:145-173

25. Kane MM, Mosser DM (2001) The role of IL-10 in promoting disease progression in leishmaniasis. J Immunol 166(2):1141-1147

26. Colotti G, Ilari A (2011) Polyamine metabolism in Leishmania: from arginine to trypanothione. Amino Acids 40(2):269-285

27. Kropf P, Fuentes JM, Fähnrich E, Arpa L, Herath S, Weber V, Soler G, Celada A, Modolell M, Müller I (2005) Arginase and polyamine synthesis are key factors in the regulation of experimental leishmaniasis in vivo. FASEB J 9(8):1000-1002

28. Iniesta V, Carcelén J, Molano I, Peixoto PM, Redondo E, Parra P, Mangas M, Monroy I, Campo ML, Nieto CG, Corraliza I (2005) Arginase I induction during Leishmania major infection mediates the development of disease. Infect Immun 73(9):6085-6090

29. Osorio EY, Zhao W, Espitia C, Saldarriaga O, Hawel L, Byus CV, Travi BL, Melby PC (2012) Progressive visceral leishmaniasis is driven by dominant parasite-induced STAT6 activation and STAT6-dependent host arginase 1 expression. PLoS Pathog 8(1):e1002417

30. França-Costa J, Van Weyenbergh J, Boaventura VS, Luz NF, Malta-Santos H, Oliveira MC, Santos de Campos DC, Saldanha AC, dos-Santos WL, Bozza PT, Barral-Netto M, Barral A, Costa JM, Borges VM, (2015) Arginase I, polyamine, and prostaglandin E2 pathways suppress the inflammatory response and contribute to diffuse cutaneous leishmaniasis. J Infect Dis 211(3):426-435

31. Mortazavi H, Sadeghipour P, Taslimi Y, Habibzadeh S, Zali F, Zahedifard F, Rahmati J, Kamyab K, Ghandi N, Zamanian A, Reza Tohidinik H, Muller I, Kropf P, Rafati S (2016) Comparing acute and chronic human cutaneous leishmaniasis caused by Leishmania major and Leishmania tropica focusing on arginase activity. J Eur Acad Dermatol Venereol 30(12):2118-2121

32. Takele Y, Abebe T, Weldegebreal T, Hailu A, Hailu W, Hurissa Z, Ali J, Diro E, Sisay Y, Cloke T, Modolell M, Munder M, Tacchini-Cottier F, Müller I, Kropf P (2013) Arginase activity in the blood of patients with visceral leishmaniasis and HIV infection. PLoS Negl Trop Dis 7(1):e1977

33. Muxel SM, Laranjeira-Silva MF, Zampieri RA, Floeter-Winter LM (2017) Leishmania (Leishmania) amazonensis induces macrophage miR-294 and miR-721 expression and modulates infection by targeting NOS 2 and L-arginine metabolism. Sci Rep 7:44141

34. Tomiotto-Pellissier F, Bortoleti B, Assolini JP, Goncalves MD, Carloto ACM, Miranda-Sapla MM, Conchon-Costa I, Bordignon J, Pavanelli WR (2018) Macrophage polarization in leishmaniasis: broadening horizons. Front Immunol 9:2529

35. Reguera RM, Balaña-Fouce R, Showalter M, Hickerson S, Beverley SM (2009) Leishmania major lacking arginase (ARG) are auxotrophic for polyamines but retain infectivity to susceptible BALB/c mice. Mol Biochem Parasitol 165(1):48-56

36. Gaur U, Roberts SC, Dalvi RP, Corraliza I, Ullman B, Wilson ME (2007) An effect of parasite-encoded arginase on the outcome of murine cutaneous leishmaniasis. J Immunol 179(12):8446-8453

37. Van Assche T, Deschacht M, da Luz RA, Maes L, Cos P (2011) Leishmania-macrophage interactions: insights into the redox biology. Free Radic Biol Med 51(2):337-351

38. Bogdan C, Röllinghoff M, Diefenbach A (2000) Reactive oxygen and reactive nitrogen intermediates in innate and specific immunity. Curr Opin Immunol 12(1):64-76

39. Novais FO, Nguyen BT, Beiting DP, Carvalho LP, Glennie ND, Passos S, Carvalho EM, Scott P (2014) Human 
classical monocytes control the intracellular stage of Leishmania braziliensis by reactive oxygen species. J Infect Dis 209(8):1288-1296

40. Bronte V, Zanovello P (2005) Regulation of immune responses by L-arginine metabolism. Nat Rev Immunol 5(8):641-654

41. Rocha FJ, Schleicher U, Mattner J, Alber G, Bogdan C (2007) Cytokines, signaling pathways, and effector molecules required for the control of Leishmania (Viannia) braziliensis in mice. Infect Immun 75(8):3823-3832

42. Carneiro PP, Conceicao J, Macedo M, Magalhaes V, Carvalho EM, Bacellar O (2016) The role of nitric oxide and reactive oxygen species in the killing of Leishmania braziliensis by monocytes from patients with cutaneous leishmaniasis. PLoS ONE 11(2):e0148084

43. Diefenbach A, Schindler H, Donhauser N, Lorenz E, Laskay T, MacMicking J, Röllinghoff M, Gresser I, Bogdan C (1998) Type 1 interferon (IFNalpha/beta) and type 2 nitric oxide synthase regulate the innate immune response to a protozoan parasite. Immunity 8(1):77-87

44. Wei XQ, Charles IG, Smith A, Ure J, Feng GJ, Huang FP, Xu D, Muller W, Moncada S, Liew FY (1995) Altered immune responses in mice lacking inducible nitric oxide synthase. Nature 375(6530):408-411

45. Gantt KR, Goldman TL, McCormick ML, Miller MA, Jeronimo SM, Nascimento ET, Britigan BE, Wilson ME (2001) Oxidative responses of human and murine macrophages during phagocytosis of Leishmania chagasi. J Immunol 167(2):893-901

46. Qadoumi M, Becker I, Donhauser N, Röllinghoff M, Bogdan C (2002) Expression of inducible nitric oxide synthase in skin lesions of patients with american cutaneous leishmaniasis. Infect Immun 70(8):4638-4642

47. Woelbing F, Kostka SL, Moelle K, Belkaid Y, Sunderkoetter C, Verbeek S, Waisman A, Nigg AP, Knop J, Udey MC, von Stebut E (2006) Uptake of Leishmania major by dendritic cells is mediated by Fcgamma receptors and facilitates acquisition of protective immunity. J Exp Med 203(1):177-188

48. von Stebut E, Belkaid Y, Jakob T, Sacks DL, Udey MC (1998) Uptake of Leishmania major amastigotes results in activation and interleukin 12 release from murine skin-derived dendritic cells: implications for the initiation of anti-Leishmania immunity. $\mathbf{J}$ Exp Med 188(8):1547-1552

49. Bertholet S, Goldszmid R, Morrot A, Debrabant A, Afrin F, Collazo-Custodio C, Houde M, Desjardins M, Sher A, Sacks D (2006) Leishmania antigens are presented to CD8+ T cells by a transporter associated with antigen processing-independent pathway in vitro and in vivo. J Immunol 177(6):3525-3533

50. Bennett CL, Misslitz A, Colledge L, Aebischer T, Blackburn CC (2001) Silent infection of bone marrow-derived dendritic cells by Leishmania mexicana amastigotes. Eur J Immunol 31(3):876-883

51. Xin L, Li K, Soong L (2008) Down-regulation of dendritic cell signaling pathways by Leishmania amazonensis amastigotes. Mol Immunol 45(12):3371-3382

52. Segura E (2016) Review of mouse and human dendritic cell subsets. In: Segura E, Onai N (eds) Methods in molecular biology (1423). Humana, New York, pp 3-15

53. Feijo D, Tiburcio R, Ampuero M, Brodskyn C, Tavares N (2016) Dendritic cells and Leishmania infection: adding layers of complexity to a complex disease. J Immunol Res 2016:3967436

54. Meredith MM, Liu K, Darrasse-Jeze G, Kamphorst AO, Schreiber HA, Guermonprez P, Idoyaga J, Cheong C, Yao KH, Niec RE, Nussenzweig MC (2012) Expression of the zinc finger transcription factor zDC (Zbtb46, Btbd4) defines the classical dendritic cell lineage. J Exp Med 209(6):1153-1165

55. Rajesh A, Wise L, Hibma M (2019) The role of Langerhans cells in pathologies of the skin. Immunol Cell Biol 97(8):700-713
56. Briseno CG, Haldar M, Kretzer NM, Wu X, Theisen DJ, Kc W, Durai V, Grajales-Reyes GE, Iwata A, Bagadia P, Murphy TL, Murphy KM (2016) Distinct transcriptional programs control cross-priming in classical and monocyte-derived dendritic cells. Cell Rep 15(11):2462-2474

57. Durai V, Murphy KM (2016) Functions of murine dendritic cells. Immunity 45(4):719-736

58. Lauvau G, Loke P, Hohl TM (2015) Monocyte-mediated defense against bacteria, fungi, and parasites. Semin Immunol 27(6):397-409

59. Merad M, Ginhoux F, Collin M (2008) Origin, homeostasis and function of Langerhans cells and other langerin-expressing dendritic cells. Nat Rev Immunol 8(12):935-947

60. Henri S, Curtis J, Hochrein H, Vremec D, Shortman K, Handman E (2002) Hierarchy of susceptibility of dendritic cell subsets to infection by Leishmania major: inverse relationship to interleukin-12 production. Infect Immun 70(7):3874-3880

61. Ashok D, Acha-Orbea H (2014) Timing is everything: dendritic cell subsets in murine Leishmania infection. Trends Parasitol 30(10):499-507

62. Ritter U, Meissner A, Scheidig C, Korner H (2004) CD8 alphaand Langerin-negative dendritic cells, but not Langerhans cells, act as principal antigen-presenting cells in leishmaniasis. Eur J Immunol 34(6):1542-1550

63. Brewig N, Kissenpfennig A, Malissen B, Veit A, Bickert T, Fleischer B, Mostbock S, Ritter U (2009) Priming of CD8+ and $\mathrm{CD} 4+\mathrm{T}$ cells in experimental leishmaniasis is initiated by different dendritic cell subtypes. J Immunol 182(2):774-783

64. Zahn S, Kirschsiefen P, Jonuleit H, Steinbrink K, Von Stebut E (2010) Human primary dendritic cell subsets differ in their IL-12 release in response to Leishmania major infection. Exp Dermatol 19(10):924-926

65. Olivier M, Gregory DJ, Forget G (2005) Subversion mechanisms by which Leishmania parasites can escape the host immune response: a signaling point of view. Clin Microbiol Rev 18(2):293-305

66. Bogdan C, Rollinghoff M (1998) The immune response to Leishmania: mechanisms of parasite control and evasion. Int J Parasitol 28(1):121-134

67. Moradin N, Descoteaux A (2012) Leishmania promastigotes: building a safe niche within macrophages. Front Cell Infect Microbiol 2:121

68. Hallé M, Gomez MA, Stuible M, Shimizu H, McMaster WR, Olivier M, Tremblay ML (2009) The Leishmania surface protease GP63 cleaves multiple intracellular proteins and actively participates in p38 mitogen-activated protein kinase inactivation. J Biol Chem 284(11):6893-6908

69. Hermoso T, Fishelson Z, Becker SI, Hirschberg K, Jaffe CL (1991) Leishmanial protein kinases phosphorylate components of the complement system. EMBO J 10(13):4061-4067

70. Lodge R, Descoteaux A (2006) Phagocytosis of Leishmania donovani amastigotes is Rac1 dependent and occurs in the absence of NADPH oxidase activation. Eur J Immunol 36(10):2735-2744

71. Nandan D, Reiner NE (1995) Attenuation of gamma interferoninduced tyrosine phosphorylation in mononuclear phagocytes infected with Leishmania donovani: selective inhibition of signaling through Janus kinases and Stat1. Infect Immun 63(11):4495-4500

72. Sen S, Roy K, Mukherjee S, Mukhopadhyay R, Roy S (2011) Restoration of IFN $\gamma \mathrm{R}$ subunit assembly, IFN $\gamma$ signaling and parasite clearance in Leishmania donovani infected macrophages: role of membrane cholesterol. PLoS Pathog 7(9):e1002229

73. Bhattacharyya S, Ghosh S, Jhonson PL, Bhattacharya SK, Majumdar S (2001) Immunomodulatory role of interleukin-10 in visceral leishmaniasis: defective activation of protein 
kinase C-mediated signal transduction events. Infect Immun 69(3):1499-1507

74. Fernandez-Figueroa EA, Imaz-Rosshandler I, Castillo-Fernandez JE, Miranda-Ortiz H, Fernandez-Lopez JC, Becker I, RangelEscareno C (2016) Down-regulation of TLR and JAK/STAT pathway genes is associated with diffuse cutaneous leishmaniasis: a gene expression analysis in nk cells from patients infected with Leishmania mexicana. PLoS Negl Trop Dis 10(3):e0004570

75. Blanchette J, Racette N, Faure R, Siminovitch KA, Olivier M (1999) Leishmania-induced increases in activation of macrophage SHP-1 tyrosine phosphatase are associated with impaired IFN-gamma-triggered JAK2 activation. Eur J Immunol 29(11):3737-3744

76. Descoteaux A, Matlashewski G, Turco SJ (1992) Inhibition of macrophage protein kinase C-mediated protein phosphorylation by Leishmania donovani lipophosphoglycan. J Immunol 149(9):3008-3015

77. Martiny A, Meyer-Fernandes JR, de Souza W, Vannier-Santos MA (1999) Altered tyrosine phosphorylation of ERK1 MAP kinase and other macrophage molecules caused by Leishmania amastigotes. Mol Biochem Parasitol 102(1):1-12

78. Yang Z, Mosser DM, Zhang X (2007) Activation of the MAPK, ERK, following Leishmania amazonensis infection of macrophages. J Immunol 178(2):1077-1085

79. Ghosh S, Bhattacharyya S, Sirkar M, Sa GS, Das T, Majumdar D, Roy S, Majumdar S (2002) Leishmania donovani suppresses activated protein 1 and NF-kappaB activation in host macrophages via ceramide generation: involvement of extracellular signalregulated kinase. Infect Immun 70(12):6828-6838

80. Forget G, Gregory DJ, Whitcombe LA, Olivier M (2006) Role of host protein tyrosine phosphatase SHP-1 in Leishmania dono$v a n i$-induced inhibition of nitric oxide production. Infect Immun 74(11):6272-6279

81. Barr SD, Gedamu L (2003) Role of peroxidoxins in Leishmania chagasi survival. Evidence of an enzymatic defense against nitrosative stress. J Biol Chem 278(12):10816-10823

82. Ghosh S, Goswami S, Adhya S (2003) Role of superoxide dismutase in survival of Leishmania within the macrophage. Biochem J 369(Pt 3):447-452

83. Sacks D, Noben-Trauth N (2002) The immunology of susceptibility and resistance to Leishmania major in mice. Nat Rev Immunol 2(11):845-858

84. Moll H, Flohe S, Rollinghoff M (1995) Dendritic cells in Leishmania major-immune mice harbor persistent parasites and mediate an antigen-specific $\mathrm{T}$ cell immune response. Eur J Immunol 25(3):693-699

85. Martinez-Valencia AJ, Daza-Rivera CF, Rosales-Chilama M, Cossio A, Casadiego Rincon EJ, Desai MM, Saravia NG, Gomez MA (2017) Clinical and parasitological factors in parasite persistence after treatment and clinical cure of cutaneous leishmaniasis. PLoS Negl Trop Dis 11(7):e0005713

86. Romero I, Tellez J, Suarez Y, Cardona M, Figueroa R, Zelazny A, Gore Saravia N (2010) Viability and burden of Leishmania in extralesional sites during human dermal leishmaniasis. PLoS Negl Trop Dis 4(9)

87. Blank C, Fuchs H, Rappersberger K, Röllinghoff M, Moll H (1993) Parasitism of epidermal Langerhans cells in experimental cutaneous leishmaniasis with Leishmania major. J Infect Dis 167(2):418-425

88. Bogdan C, Donhauser N, Doring R, Rollinghoff M, Diefenbach A, Rittig MG (2000) Fibroblasts as host cells in latent leishmaniosis. J Exp Med 191(12):2121-2130

89. McConville MJ, Naderer T (2011) Metabolic pathways required for the intracellular survival of Leishmania. Ann Rev Microbiol 65:543-561
90. Rosenzweig D, Smith D, Opperdoes F, Stern S, Olafson RW, Zilberstein D (2008) Retooling Leishmania metabolism: from sand fly gut to human macrophage. FASEB J 22(2):590-602

91. Saunders EC, DP DES, Naderer T, Sernee MF, Ralton JE, Doyle MA, Macrae JI, Chambers JL, Heng J, Nahid A, Likic VA, McConville MJ, (2010) Central carbon metabolism of Leishmania parasites. Parasitology 137(9):1303-1313

92. Forestier CL, Gao Q, Boons GJ (2014) Leishmania lipophosphogly can: how to establish structure-activity relationships for this highly complex and multifunctional glycoconjugate? Front Cell Infect Microbiol 4:193

93. Brandonisio O, Panaro MA, Marzio R, Marangi A, Faliero SM, Jirillo E (1994) Impairment of the human phagocyte oxidative responses caused by Leishmania lipophosphoglycan (LPG): in vitro studies. FEMS Immunol Med Microbiol 8(1):57-62

94. Rodríguez NE, Lockard RD, Turcotte EA, Araújo-Santos T, Bozza PT, Borges VM, Wilson ME (2017) Lipid bodies accumulation in Leishmania infantum-infected C57BL/6 macrophages. Parasite Immunol 39(8)

95. Flannery AR, Renberg RL, Andrews NW (2013) Pathways of iron acquisition and utilization in Leishmania. Curr Opin Microbiol 16(6):716-721

96. Dighal A, Mukhopadhyay D, Sengupta R, Moulik S, Mukherjee S, Roy S, Chaudhuri SJ, Das NK, Chatterjee M (2020) Iron trafficking in patients with Indian Post kala-azar dermal leishmaniasis. PLoS Negl Trop Dis 14(2):e0007991

97. Singh N, Bajpai S, Kumar V, Gour JK, Singh RK (2013) Identification and functional characterization of Leishmania donovani secretory peroxidase: delineating its role in NRAMP1 regulation. PLoS ONE 8(1):e53442

98. Ben-Othman R, Flannery AR, Miguel DC, Ward DM, Kaplan J, Andrews NW (2014) Leishmania-mediated inhibition of iron export promotes parasite replication in macrophages. PLoS Pathog 10(1):e1003901

99. Podinovskaia M, Descoteaux A (2015) Leishmania and the macrophage: a multifaceted interaction. Future Microbiol 10(1):111-129

100. Sypek JP, Chung CL, Mayor SE, Subramanyam JM, Goldman SJ, Sieburth DS, Wolf SF, Schaub RG (1993) Resolution of cutaneous leishmaniasis: interleukin 12 initiates a protective $\mathrm{T}$ helper type 1 immune response. J Exp Med 177(6):1797-1802

101. Scharton-Kersten T, Afonso LC, Wysocka M, Trinchieri G, Scott $P$ (1995) IL-12 is required for natural killer cell activation and subsequent $\mathrm{T}$ helper 1 cell development in experimental leishmaniasis. J Immunol 154(10):5320-5330

102. Scott P (2003) Development and regulation of cell-mediated immunity in experimental leishmaniasis. Immunol Res 27(2-3):489-498

103. Heinzel FP, Rerko RM, Ahmed F, Pearlman E (1995) Endogenous IL-12 is required for control of Th2 cytokine responses capable of exacerbating leishmaniasis in normally resistant mice. J Immunol 155(2):730-739

104. Reiner SL, Zheng S, Wang ZE, Stowring L, Locksley RM (1994) Leishmania promastigotes evade interleukin 12 (IL-12) induction by macrophages and stimulate a broad range of cytokines from CD4+ T cells during initiation of infection. J Exp Med 179(2):447-456

105. Mattner F, Magram J, Ferrante J, Launois P, Di Padova K, Behin R, Gately MK, Louis JA, Alber G (1996) Genetically resistant mice lacking interleukin-12 are susceptible to infection with Leishmania major and mount a polarized Th2 cell response. Eur J Immunol 26(7):1553-1559

106. Park AY, Hondowicz BD, Scott P (2000) IL-12 is required to maintain a Th1 response during Leishmania major infection. J Immunol 165(2):896-902 
107. Hondowicz BD, Park AY, Elloso MM, Scott P (2000) Maintenance of IL-12-responsive CD4+ T cells during a Th2 response in Leishmania major-infected mice. Eur J Immunol 30(7):2007-2014

108. Heinzel FP, Schoenhaut DS, Rerko RM, Rosser LE, Gately MK (1993) Recombinant interleukin 12 cures mice infected with Leishmania major. J Exp Med 177(5):1505-1509

109. Stobie L, Gurunathan S, Prussin C, Sacks DL, Glaichenhaus $\mathrm{N}$, Wu CY, Seder RA (2000) The role of antigen and IL-12 in sustaining Th1 memory cells in vivo: IL-12 is required to maintain memory/effector Th1 cells sufficient to mediate protection to an infectious parasite challenge. Proc Natl Acad Sci USA 97(15):8427-8432

110. Okwor I, Uzonna JE (2016) Pathways leading to interleukin-12 production and protective immunity in cutaneous leishmaniasis. Cell Immunol 309:32-36

111. von Stebut E, Udey MC (2004) Requirements for Th1-dependent immunity against infection with Leishmania major. Microbes Infect 6(12):1102-1109

112. Von Stebut E, Ehrchen JM, Belkaid Y, Kostka SL, Molle K, Knop J, Sunderkotter C, Udey MC (2003) Interleukin 1alpha promotes Th1 differentiation and inhibits disease progression in Leishmania major-susceptible BALB/c mice. J Exp Med 198(2):191-199

113. Park AY, Hondowicz B, Kopf M, Scott P (2002) The role of IL-12 in maintaining resistance to Leishmania major. J Immunol 168(11):5771-5777

114. Habibi GR, Khamesipour A, McMaster WR, Mahboudi F (2001) Cytokine gene expression in healing and non-healing cases of cutaneous leishmaniasis in response to in vitro stimulation with recombinant gp63 using semi-quantitative RT-PCR. Scand J Immunol 54(4):414-420

115. Valencia-Pacheco G, Loria-Cervera EN, Sosa-Bibiano EI, Canche-Pool EB, Vargas-Gonzalez A, Melby PC, AndradeNarvaez FJ (2014) In situ cytokines (IL-4, IL-10, IL-12, IFNgamma) and chemokines (MCP-1, MIP-1alpha) gene expression in human Leishmania (Leishmania) mexicana infection. Cytokine 69(1):56-61

116. Melby PC, Andrade-Narvaez F, Darnell BJ, Valencia-Pacheco G (1996) In situ expression of interleukin-10 and interleukin-12 in active human cutaneous leishmaniasis. FEMS Immunol Med Microbiol 15(2-3):101-107

117. Bourreau E, Prevot G, Pradinaud R, Launois P (2001) Unresponsiveness of specific $\mathrm{T}$ cells to IL-12 is associated with active cutaneous leishmaniasis owing to Leishmania guyanensis. Scand J Immunol 54(3):335-339

118. Afonso LC, Scharton TM, Vieira LQ, Wysocka M, Trinchieri G, Scott P (1994) The adjuvant effect of interleukin-12 in a vaccine against Leishmania major. Science 263(5144):235-237

119. Kenney RT, Sacks DL, Sypek JP, Vilela L, Gam AA, EvansDavis K (1999) Protective immunity using recombinant human IL-12 and alum as adjuvants in a primate model of cutaneous leishmaniasis. J Immunol 163(8):4481-4488

120. Gicheru MM, Olobo JO, Anjili CO, Orago AS, Modabber F, Scott P (2001) Vervet monkeys vaccinated with killed Leishmania major parasites and interleukin-12 develop a type 1 immune response but are not protected against challenge infection. Infect Immun 69(1):245-251

121. Raman VS, Duthie MS, Fox CB, Matlashewski G, Reed SG (2012) Adjuvants for Leishmania vaccines: from models to clinical application. Front Immunol 3:144

122. Engwerda CR, Murphy ML, Cotterell SE, Smelt SC, Kaye PM (1998) Neutralization of IL-12 demonstrates the existence of discrete organ-specific phases in the control of Leishmania donovani. Eur J Immunol 28(2):669-680
123. Murray HW (1997) Endogenous interleukin-12 regulates acquired resistance in experimental visceral leishmaniasis. J Infect Dis 175(6):1477-1479

124. Taylor AP, Murray HW (1997) Intracellular antimicrobial activity in the absence of interferon-gamma: effect of interleukin-12 in experimental visceral leishmaniasis in interferon-gamma genedisrupted mice. J Exp Med 185(7):1231-1239

125. Ato M, Maroof A, Zubairi S, Nakano H, Kakiuchi T, Kaye PM (2006) Loss of dendritic cell migration and impaired resistance to Leishmania donovani infection in mice deficient in CCL19 and CCL21. J Immunol 176(9):5486-5493

126. Gorak PM, Engwerda CR, Kaye PM (1998) Dendritic cells, but not macrophages, produce IL-12 immediately following Leishmania donovani infection. Eur J Immunol 28(2):687-695

127. Schleicher U, Liese J, Knippertz I, Kurzmann C, Hesse A, Heit A, Fischer JA, Weiss S, Kalinke U, Kunz S, Bogdan C (2007) NK cell activation in visceral leishmaniasis requires TLR9, myeloid DCs, and IL-12, but is independent of plasmacytoid DCs. J Exp Med 204(4):893-906

128. Kurkjian KM, Mahmutovic AJ, Kellar KL, Haque R, Bern C, Secor WE (2006) Multiplex analysis of circulating cytokines in the sera of patients with different clinical forms of visceral leishmaniasis. Cytometry A 69(5):353-358

129. Sundar S, Reed SG, Sharma S, Mehrotra A, Murray HW (1997) Circulating T helper 1 (Th1) cell- and Th2 cell-associated cytokines in Indian patients with visceral leishmaniasis. Am J Trop Med Hyg 56(5):522-525

130. Ghalib HW, Whittle JA, Kubin M, Hashim FA, el-Hassan AM, Grabstein KH, Trinchieri G, Reed SG (1995) IL-12 enhances Th1-type responses in human Leishmania donovani infections. J Immunol 154(9):4623-4629

131. Bacellar O, Brodskyn C, Guerreiro J, Barral-Netto M, Costa CH, Coffman RL, Johnson WD, Carvalho EM (1996) Interleukin-12 restores interferon-gamma production and cytotoxic responses in visceral leishmaniasis. J Infect Dis 173(6):1515-1518

132. Nasseri M, Modabber FZ (1979) Generalized infection and lack of delayed hypersensitivity in BALB/c mice infected with Leishmania tropica major. Infect Immun 26(2):611-614

133. Scott P, Novais FO (2016) Cutaneous leishmaniasis: immune responses in protection and pathogenesis. Nat Rev Immunol 16(9):581-592

134. Reiner SL, Locksley RM (1995) The regulation of immunity to Leishmania major. Ann Rev Immunol 13:151-177

135. Kedzierski L, Evans KJ (2014) Immune responses during cutaneous and visceral leishmaniasis. Parasitology 1-19

136. Nateghi Rostami M, Seyyedan Jasbi E, Khamesipour A, Mohammadi AM (2016) Tumour necrosis factor-alpha (TNF-alpha) and its soluble receptor type 1 (sTNFR I) in human active and healed leishmaniases. Parasite Immunol 38(4):255-260

137. Bamorovat M, Sharifi I, Aflatoonian MR, Sadeghi B, Shafiian A, Oliaee RT, Keyhani A, Afshar AA, Khosravi A, Mostafavi M, Parizi MH, Khatami M, Arefinia N (2019) Host's immune response in unresponsive and responsive patients with anthroponotic cutaneous leishmaniasis treated by meglumine antimoniate: a case-control study of Th1 and Th2 pathways. Int Immunopharmacol 69:321-327

138. Egui A, Ledesma D, Perez-Anton E, Montoya A, Gomez I, Robledo SM, Infante JJ, Velez ID, Lopez MC, Thomas MC (2018) Phenotypic and functional profiles of antigen-specific CD4(+) and CD8(+) T cells associated with infection control in patients with cutaneous leishmaniasis. Front Cell Infect Microbiol 8:393

139. Ansari NA, Ramesh V, Salotra P (2006) Interferon (IFN)gamma, tumor necrosis factor-alpha, interleukin-6, and IFNgamma receptor 1 are the major immunological determinants 
associated with post-kala azar dermal leishmaniasis. J Infect Dis 194(7):958-965

140. Diaz NL, Zerpa O, Ponce LV, Convit J, Rondon AJ, Tapia FJ (2002) Intermediate or chronic cutaneous leishmaniasis: leukocyte immunophenotypes and cytokine characterisation of the lesion. Exp Dermatol 11(1):34-41

141. Castellano LR, Filho DC, Argiro L, Dessein H, Prata A, Dessein A, Rodrigues V (2009) Th1/Th2 immune responses are associated with active cutaneous leishmaniasis and clinical cure is associated with strong interferon-gamma production. Hum Immunol 70(6):383-390

142. Ajdary S, Riazi-Rad F, Alimohammadian MH, Pakzad SR (2009) Immune response to Leishmania antigen in anthroponotic cutaneous leishmaniasis. J Infect 59(2):139-143

143. Babaloo Z, Kaye PM, Eslami MB (2001) Interleukin-13 in Iranian patients with visceral leishmaniasis: relationship to other Th2 and Th1 cytokines. Trans R Soc Trop Med Hyg 95(1):85-88

144. Kemp M, Kurtzhals JA, Bendtzen K, Poulsen LK, Hansen MB, Koech DK, Kharazmi A, Theander TG (1993) Leishmania donovani-reactive Th1- and Th2-like T-cell clones from individuals who have recovered from visceral leishmaniasis. Infect Immun 61(3):1069-1073

145. Karp CL, El-Safi SH, Wynn TA, Satti MM, Kordofani AM, Hashim FA, Hag-Ali M, Neva FA, Nutman TB, Sacks DL (1993) In vivo cytokine profiles in patients with kala-azar. Marked elevation of both interleukin-10 and interferon-gamma. J Clin Invest 91(4):1644-1648

146. Kammoun-Rebai W, Naouar I, Libri V, Albert M, Louzir H, Meddeb-Garnaoui A, Duffy D (2016) Protein biomarkers discriminate Leishmania major-infected and non-infected individuals in areas endemic for cutaneous leishmaniasis. BMC Infect Dis $16: 138$

147. Caceres-Dittmar G, Tapia FJ, Sanchez MA, Yamamura M, Uyemura K, Modlin RL, Bloom BR, Convit J (1993) Determination of the cytokine profile in American cutaneous leishmaniasis using the polymerase chain reaction. Clin Exp Immun 91(3):500-505

148. Nateghi RM, Keshavarz VH, Eskandari SE, Miramin MA, Shahrestani ST, Sarraf-Nejad A, Khamesipour A (2010) Differential in vitro CD4+/CD8+ T-cell response to live vs killed Leishmania major. Parasite Immunol 32(2):101-110

149. Mahmoodi M, Rajabalian S, Fekri A, Esfandiarpour I (2005) Evaluation of in vitro production of ifn-gamma, il-10, il-12 and il-13 by blood cells in patients with cutaneous leishmaniasis lesions. Iran J Allergy Asthma Immunol 4(1):15-21

150. Nateghi Rostami M, Seyyedan Jasbi E, Khamesipour A, Miramin Mohammadi A (2015) Plasma levels of tumor necrosis factoralpha (TNF-alpha), TNF-alpha soluble receptor type 1 (sTNFR I) and IL-22 in human leishmaniasis. Trop Biomed 32(3):478-484

151. Khamesipour A, Nateghi Rostami M, Tasbihi M, Miramin Mohammadi A, Shahrestani T, Sarrafnejad A, Sohrabi Y, Eskandari SE, Keshavarz Valian H (2012) Phenotyping of circulating CD8(+) T cell subsets in human cutaneous leishmaniasis. Microbes Infect 14(9):702-711

152. Keshavarz Valian H, Nateghi Rostami M, Tasbihi M, Miramin Mohammadi A, Eskandari SE, Sarrafnejad A, Khamesipour A (2013) CCR7+ central and CCR7- effector memory CD4+ $\mathrm{T}$ cells in human cutaneous leishmaniasis. J Clin Immunol 33(1):220-234

153. Miramin-Mohammadi A, Javadi A, Eskandari SE, Mortazavi H, Rostami MN, Khamesipour A (2020) Immune response in cutaneous leishmaniasis patients with healing vs. non-healing lesions. Iran J Microbiol 12(3):249-255

154. Castro Gomes CM, Sousa MGT, Menezes JPB, Batista MC, Lima ACS, Belda W Jr, Bradshaw D, Gama MEA, Laurenti MD, Silveira FT, Corbett CEP (2017) Immunopathological characterization of human cutaneous leishmaniasis lesions caused by Leishmania (Viannia) spp, Amazonian Brazil. Parasitol Res 116(5):1423-1431

155. Campos-Neto A (2005) What about Th1/Th2 in cutaneous leishmaniasis vaccine discovery? Braz J Med Biol Res 38(7):979-984

156. Mougneau E, Altare F, Wakil AE, Zheng S, Coppola T, Wang ZE, Waldmann R, Locksley RM, Glaichenhaus N (1995) Expression cloning of a protective Leishmania antigen. Science 268(5210):563-566

157. Julia V, Rassoulzadegan M, Glaichenhaus N (1996) Resistance to Leishmania major induced by tolerance to a single antigen. Science 274(5286):421-423

158. Pollock KG, McNeil KS, Mottram JC, Lyons RE, Brewer JM, Scott P, Coombs GH, Alexander J (2003) The Leishmania mexicana cysteine protease, CPB2.8, induces potent $\mathrm{Th} 2$ responses. $\mathrm{J}$ Immunol 170(4):1746-1753

159. Gaafar A, Veress B, Permin H, Kharazmi A, Theander TG, el Hassan AM (1999) Characterization of the local and systemic immune responses in patients with cutaneous leishmaniasis due to Leishmania major. Clin Immunol 91(3):314-320

160. Santos CS, Boaventura V, Ribeiro Cardoso C, Tavares N, Lordelo MJ, Noronha A, Costa J, Borges VM, de Oliveira CI, Van Weyenbergh J, Barral A, Barral-Netto M, Brodskyn CI (2013) $\mathrm{CD} 8(+)$ granzyme $\mathrm{B}(+)$-mediated tissue injury vs. CD4(+) IFNgamma(+)-mediated parasite killing in human cutaneous leishmaniasis. J Invest Dermatol 133(6):1533-1540

161. Louzir H, Melby PC, Ben Salah A, Marrakchi H, Aoun K, Ben Ismail R, Dellagi K (1998) Immunologic determinants of disease evolution in localized cutaneous leishmaniasis due to Leishmania major. J Infect Dis 177(6):1687-1695

162. Kemp K, Theander TG, Hviid L, Garfar A, Kharazmi A, Kemp M (1999) Interferon-gamma- and tumour necrosis factor-alphaproducing cells in humans who are immune to cutaneous leishmaniasis. Scand J Immunol 49(6):655-659

163. Muniz AC, Bacellar O, Lago EL, Carvalho AM, Carneiro PP, Guimaraes LH, Rocha PN, Carvalho LP, Glesby M, Carvalho EM (2016) Immunologic markers of protection in Leishmania (Viannia) braziliensis infection: a 5-Year cohort study. J Infect Dis 214(4):570-576

164. Nateghi Rostami M, Keshavarz H, Edalat R, Sarrafnejad A, Shahrestani T, Mahboudi F, Khamesipour A (2010) CD8+ T cells as a source of IFN-gamma production in human cutaneous leishmaniasis. PLoS Negl Trop Dis 4(10):e845

165. Scharton TM, Scott P (1993) Natural killer cells are a source of interferon gamma that drives differentiation of CD4+ T cell subsets and induces early resistance to Leishmania major in mice. J Exp Med 178(2):567-577

166. Rai AK, Thakur CP, Kumar P, Saini S, Kureel AK, Kumari S, Seth T, Mitra DK (2018) Decrease in the frequency of circulating CD56(+)CD161(+) NK cells in human visceral leishmaniasis. Immunol Invest 47(2):125-134

167. Bogdan C (2012) Natural killer cells in experimental and human leishmaniasis. Front Cell Infect Microbiol 2:69

168. Maspi N, Abdoli A, Ghaffarifar F (2016) Pro- and anti-inflammatory cytokines in cutaneous leishmaniasis: a review. Pathog Glob Health 110(6):247-260

169. Ho JL, Badaro R, Schwartz A, Dinarello CA, Gelfand JA, Sobel J, Barral A, Netto MB, Carvalho EM, Reed SG et al (1992) Diminished in vitro production of interleukin-1 and tumor necrosis factor-alpha during acute visceral leishmaniasis and recovery after therapy. J Infect Dis 165(6):1094-1102

170. Saha S, Mondal S, Ravindran R, Bhowmick S, Modak D, Mallick S, Rahman M, Kar S, Goswami R, Guha SK, Pramanik N, Saha B, Ali N (2007) IL-10- and TGF-beta-mediated susceptibility in kala-azar and post-kala-azar dermal leishmaniasis: 
the significance of amphotericin B in the control of Leishmania donovani infection in India. J Immunol 179(8):5592-5603

171. Singh OP, Sundar S (2014) Whole blood assay and visceral leishmaniasis: Challenges and promises. Immunobiology 219(4):323-328

172. Kumar R, Singh N, Gautam S, Singh OP, Gidwani K, Rai M, Sacks D, Sundar S, Nylen S (2014) Leishmania specific CD4 $\mathrm{T}$ cells release IFNgamma that limits parasite replication in patients with visceral leishmaniasis. PLoS Negl Trop Dis 8(10):e3198

173. Garg R, Gupta SK, Tripathi P, Naik S, Sundar S, Dube A (2005) Immunostimulatory cellular responses of cured Leishmaniainfected patients and hamsters against the integral membrane proteins and non-membranous soluble proteins of a recent clinical isolate of Leishmania donovani. Clin Exp Immunol 140(1):149-156

174. Nylén S, Maurya R, Eidsmo L, Manandhar KD, Sundar S, Sacks $\mathrm{D}$ (2007) Splenic accumulation of IL-10 mRNA in T cells distinct from CD4+CD25+ (Foxp3) regulatory T cells in human visceral leishmaniasis. J Exp Med 204(4):805-817

175. Tripathi P, Ray S, Sunder S, Dube A, Naik S (2006) Identification of Leishmania donovani antigens stimulating cellular immune responses in exposed immune individuals. Clin Exp Immunol 143(2):380-388

176. Murray HW (2001) Tissue granuloma structure-function in experimental visceral leishmaniasis. Int J Exp Pathol 82(5):249-267

177. Salguero FJ, Garcia-Jimenez WL, Lima I, Seifert K (2018) Histopathological and immunohistochemical characterisation of hepatic granulomas in Leishmania donovani-infected BALB/c mice: a time-course study. Parasit Vectors 11(1):73

178. Murray HW, Hariprashad J, Aguero B, Arakawa T, Yeganegi $\mathrm{H}$ (1995) Antimicrobial response of a T cell-deficient host to cytokine therapy: effect of interferon-gamma in experimental visceral leishmaniasis in nude mice. J Infect Dis 171(5):1309-1316

179. Murray HW (1990) Effect of continuous administration of interferon-gamma in experimental visceral leishmaniasis. J Infect Dis 161(5):992-994

180. Badaro R, Johnson WD Jr (1993) The role of interferon-gamma in the treatment of visceral and diffuse cutaneous leishmaniasis. J Infect Dis 167(Suppl 1):S13-17

181. Schroder K, Hertzog PJ, Ravasi T, Hume DA (2004) Interferongamma: an overview of signals, mechanisms and functions. $\mathrm{J}$ Leukoc Biol 75(2):163-189

182. Boehm U, Klamp T, Groot M, Howard JC (1997) Cellular responses to interferon-gamma. Ann Rev Immunol 15:749-795

183. Durbin JE, Hackenmiller R, Simon MC, Levy DE (1996) Targeted disruption of the mouse Stat 1 gene results in compromised innate immunity to viral disease. Cell 84(3):443-450

184. Darnell JE Jr (1997) STATs and gene regulation. Science 277(5332):1630-1635

185. Rosas LE, Keiser T, Pyles R, Durbin J, Satoskar AR (2003) Development of protective immunity against cutaneous leishmaniasis is dependent on STAT1-mediated IFN signaling pathway. Eur J Immunol 33(7):1799-1805

186. Späth GF, Schlesinger P, Schreiber R, Beverley SM (2009) A novel role for Stat 1 in phagosome acidification and natural host resistance to intracellular infection by Leishmania major. PLoS Pathog 5(4):e1000381

187. Leal LM, Moss DW, Kuhn R, Muller W, Liew FY (1993) Interleukin-4 transgenic mice of resistant background are susceptible to Leishmania major infection. Eur J Immunol 23(2):566-569

188. Himmelrich H, Launois P, Maillard I, Biedermann T, TacchiniCottier F, Locksley RM, Rocken M, Louis JA (2000) In BALB/c mice, IL-4 production during the initial phase of infection with Leishmania major is necessary and sufficient to instruct Th2 cell development resulting in progressive disease. J Immunol 164(9):4819-4825

189. Heinzel FP, Sadick MD, Holaday BJ, Coffman RL, Locksley RM (1989) Reciprocal expression of interferon gamma or interleukin 4 during the resolution or progression of murine leishmaniasis. Evidence for expansion of distinct helper T cell subsets. J Exp Med 169(1):59-72

190. Chatelain R, Varkila K, Coffman RL (1992) IL-4 induces a Th2 response in Leishmania major-infected mice. J Immunol 148(4):1182-1187

191. Alexander J, Brombacher F, McGachy HA, McKenzie AN, Walker W, Carter KC (2002) An essential role for IL-13 in maintaining a non-healing response following Leishmania mexicana infection. Eur J Immunol 32(10):2923-2933

192. Kopf M, Brombacher F, Köhler G, Kienzle G, Widmann KH, Lefrang K, Humborg C, Ledermann B, Solbach W (1996) IL4-deficient Balb/c mice resist infection with Leishmania major. J Exp Med 184(3):1127-1136

193. Himmelrich H, Parra-Lopez C, Tacchini-Cottier F, Louis JA, Launois P (1998) The IL-4 rapidly produced in BALB/c mice after infection with Leishmania major down-regulates IL-12 receptor beta 2-chain expression on CD4+ T cells resulting in a state of unresponsiveness to IL-12. J Immunol 161(11):6156-6163

194. Jones D, Elloso MM, Showe L, Williams D, Trinchieri G, Scott $P$ (1998) Differential regulation of the interleukin-12 receptor during the innate immune response to Leishmania major. Infect Immun 66(8):3818-3824

195. Launois P, Maillard I, Pingel S, Swihart KG, Xenarios I, AchaOrbea H, Diggelmann H, Locksley RM, MacDonald HR, Louis JA (1997) IL-4 rapidly produced by V beta $4 \mathrm{~V}$ alpha 8 CD4+ T cells instructs Th2 development and susceptibility to Leishmania major in BALB/c mice. Immunity 6(5):541-549

196. Jones DE, Buxbaum LU, Scott P (2000) IL-4-independent inhibition of IL-12 responsiveness during Leishmania amazonensis infection. J Immunol 165(1):364-372

197. Mohrs M, Ledermann B, Köhler G, Dorfmüller A, Gessner A, Brombacher F (1999) Differences between IL-4- and IL-4 receptor alpha-deficient mice in chronic leishmaniasis reveal a protective role for IL-13 receptor signaling. J Immunol 162(12):7302-7308

198. Noben-Trauth N (2000) Susceptibility to Leishmania major infection in the absence of IL-4. Immunol Lett 75(1):41-44

199. Biedermann T, Zimmermann S, Himmelrich H, Gumy A, Egeter O, Sakrauski AK, Seegmuller I, Voigt H, Launois P, Levine AD, Wagner H, Heeg K, Louis JA, Rocken M (2001) IL-4 instructs TH1 responses and resistance to Leishmania major in susceptible BALB/c mice. Nat Immunol 2(11):1054-1060

200. Bogdan C, Stenger S, Röllinghoff M, Solbach W (1991) Cytokine interactions in experimental cutaneous leishmaniasis. Interleukin 4 synergizes with interferon-gamma to activate murine macrophages for killing of Leishmania major amastigotes. Eur J Immunol 21(2):327-333

201. Mahmoodi M, Khamesipour A, Dowlati Y, Rafati S, Momeni AZ, Emamjomeh M, Hejazi H, Modabber F (2003) Immune response measured in human volunteers vaccinated with autoclaved Leishmania major vaccine mixed with low dose of BCG. Clin Exp Immunol 134(2):303-308

202. Boussoffara T, Boubaker MS, Ben Ahmed M, Mokni M, Guizani I, Ben Salah A, Louzir H (2019) Histological and immunological differences between zoonotic cutaneous leishmaniasis due to Leishmania major and sporadic cutaneous leishmaniasis due to Leishmania infantum. Parasite 26:9

203. Pirmez C, Yamamura M, Uyemura K, Paes-Oliveira M, Conceicao-Silva F, Modlin RL (1993) Cytokine patterns in the pathogenesis of human leishmaniasis. J Clin Invest 91(4):1390-1395 
204. Bourreau E, Prevot G, Pradinaud R, Launois P (2001) Interleukin (IL)-13 is the predominant Th2 cytokine in localized cutaneous leishmaniasis lesions and renders specific CD4+ T cells unresponsive to IL-12. J Infect Dis 183(6):953-959

205. D'Oliveira A Jr, Machado P, Bacellar O, Cheng LH, Almeida RP, Carvalho EM (2002) Evaluation of IFN-gamma and TNFalpha as immunological markers of clinical outcome in cutaneous leishmaniasis. Rev Soc Bras Med Trop 35(1):7-10

206. Da-Cruz AM, de Oliveira MP, De Luca PM, Mendonca SC, Coutinho SG (1996) Tumor necrosis factor-alpha in human american tegumentary leishmaniasis. Mem Inst Oswaldo Cruz 91(2):225-229

207. Antonelli LR, Dutra WO, Almeida RP, Bacellar O, Carvalho EM, Gollob KJ (2005) Activated inflammatory T cells correlate with lesion size in human cutaneous leishmaniasis. Immunol Lett 101(2):226-230

208. Brelaz-de-Castro MCA, de Almeida TM, de Almeida AF, de Assis SM, de Oliveira Mendes AP, Silva RFE, de Brito MEF, Pereira VRA (2018) Combination of flow cytometry and qPCR to study the immune response of american cutaneous leishmaniasis patients. Microb Pathog 123:433-439

209. Green SJ, Crawford RM, Hockmeyer JT, Meltzer MS, Nacy CA (1990) Leishmania major amastigotes initiate the L-argininedependent killing mechanism in IFN-gamma-stimulated macrophages by induction of tumor necrosis factor-alpha. J Immunol 145(12):4290-4297

210. Bogdan C, Moll H, Solbach W, Rollinghoff M (1990) Tumor necrosis factor-alpha in combination with interferon-gamma, but not with interleukin 4 activates murine macrophages for elimination of Leishmania major amastigotes. Eur J Immunol 20(5):1131-1135

211. Melby PC, Andrade-Narvaez FJ, Darnell BJ, Valencia-Pacheco G, Tryon VV, Palomo-Cetina A (1994) Increased expression of proinflammatory cytokines in chronic lesions of human cutaneous leishmaniasis. Infect Immun 62(3):837-842

212. Schleicher U, Paduch K, Debus A, Obermeyer S, König T, Kling JC, Ribechini E, Dudziak D, Mougiakakos D, Murray PJ, Ostuni R, Körner H, Bogdan C (2016) TNF-mediated restriction of arginase 1 expression in myeloid cells triggers type 2 no synthase activity at the site of infection. Cell Rep 15(5):1062-1075

213. Murray HW, Jungbluth A, Ritter E, Montelibano C, Marino MW (2000) Visceral leishmaniasis in mice devoid of tumor necrosis factor and response to treatment. Infect immun 68(11):6289-6293

214. Tumang MC, Keogh C, Moldawer LL, Helfgott DC, Teitelbaum R, Hariprashad J, Murray HW (1994) Role and effect of TNF-alpha in experimental visceral leishmaniasis. J Immunol 153(2):768-775

215. Stanley AC, Engwerda CR (2007) Balancing immunity and pathology in visceral leishmaniasis. Immunol Cell Biol 85(2):138-147

216. Peters N, Sacks D (2006) Immune privilege in sites of chronic infection: Leishmania and regulatory T cells. Immunol Rev 213:159-179

217. Belkaid Y (2003) The role of CD4(+)CD25(+) regulatory T cells in Leishmania infection. Expert Opin Biol Ther 3(6):875-885

218. Taga K, Tosato G (1992) IL-10 inhibits human T cell proliferation and IL-2 production. J Immunol 148(4):1143-1148

219. Fiorentino DF, Zlotnik A, Mosmann TR, Howard M, O'Garra A (1991) IL-10 inhibits cytokine production by activated macrophages. J Immunol 147(11):3815-3822

220. Vieth M, Will A, Schroppel K, Rollinghoff M, Gessner A (1994) Interleukin-10 inhibits antimicrobial activity against Leishmania major in murine macrophages. Scand J Immunol 40(4):403-409

221. Gazzinelli RT, Oswald IP, James SL, Sher A (1992) IL-10 inhibits parasite killing and nitrogen oxide production by IFN-gamma-activated macrophages. J Immunol 148(6):1792-1796

222. Bogdan C, Vodovotz Y, Nathan C (1991) Macrophage deactivation by interleukin 10. J Exp Med 174(6):1549-1555

223. Belkaid Y, Piccirillo CA, Mendez S, Shevach EM, Sacks DL (2002) CD4+CD25+ regulatory T cells control Leishmania major persistence and immunity. Nature 420(6915):502-507

224. Anderson CF, Oukka M, Kuchroo VJ, Sacks D (2007) CD4(+) CD25(-)Foxp3(-) Th1 cells are the source of IL-10-mediated immune suppression in chronic cutaneous leishmaniasis. J Exp Med 204(2):285-297

225. Belkaid Y, Hoffmann KF, Mendez S, Kamhawi S, Udey MC, Wynn TA, Sacks DL (2001) The role of interleukin (IL)-10 in the persistence of Leishmania major in the skin after healing and the therapeutic potential of anti-IL-10 receptor antibody for sterile cure. J Exp Med 194(10):1497-1506

226. Murray HW, Lu CM, Mauze S, Freeman S, Moreira AL, Kaplan G, Coffman RL (2002) Interleukin-10 (IL-10) in experimental visceral leishmaniasis and IL-10 receptor blockade as immunotherapy. Infect Immun 70(11):6284-6293

227. Oliveira WN, Ribeiro LE, Schrieffer A, Machado P, Carvalho EM, Bacellar O (2014) The role of inflammatory and antiinflammatory cytokines in the pathogenesis of human tegumentary leishmaniasis. Cytokine 66(2):127-132

228. Faria DR, Gollob KJ, Barbosa J Jr, Schriefer A, Machado PR, Lessa H, Carvalho LP, Romano-Silva MA, de Jesus AR, Carvalho EM, Dutra WO (2005) Decreased in situ expression of interleukin-10 receptor is correlated with the exacerbated inflammatory and cytotoxic responses observed in mucosal leishmaniasis. Infect Immun 73(12):7853-7859

229. Bacellar O, Lessa H, Schriefer A, Machado P, Ribeiro de Jesus A, Dutra WO, Gollob KJ, Carvalho EM (2002) Up-regulation of Th1-type responses in mucosal leishmaniasis patients. Infect Immun 70(12):6734-6740

230. Nylen S, Sacks D (2007) Interleukin-10 and the pathogenesis of human visceral leishmaniasis. Trends Immunol 28(9):378-384

231. Valeri M, Raffatellu M (2016) Cytokines IL-17 and IL-22 in the host response to infection. Pathog Dis 74(9)

232. Lopez Kostka S, Dinges S, Griewank K, Iwakura Y, Udey MC, von Stebut E (2009) IL-17 promotes progression of cutaneous leishmaniasis in susceptible mice. J Immunol 182(5):3039-3046

233. Gonzalez-Lombana C, Gimblet C, Bacellar O, Oliveira WW, Passos S, Carvalho LP, Goldschmidt M, Carvalho EM, Scott P (2013) IL-17 mediates immunopathology in the absence of IL-10 following Leishmania major infection. PLoS Pathog 9(3):e1003243

234. Bacellar O, Faria D, Nascimento M, Cardoso TM, Gollob KJ, Dutra WO, Scott P, Carvalho EM (2009) Interleukin 17 production among patients with American cutaneous leishmaniasis. J Infect Dis 200(1):75-78

235. Boaventura VS, Santos CS, Cardoso CR, de Andrade J, Dos Santos WL, Clarencio J, Silva JS, Borges VM, Barral-Netto M, Brodskyn CI, Barral A (2010) Human mucosal leishmaniasis: neutrophils infiltrate areas of tissue damage that express high levels of Th17-related cytokines. Eur J Immunol 40(10):2830-2836

236. Pitta MG, Romano A, Cabantous S, Henri S, Hammad A, Kouriba B, Argiro L, el Kheir M, Bucheton B, Mary C, El-Safi SH, Dessein A (2009) IL-17 and IL-22 are associated with protection against human kala azar caused by Leishmania donovani. J Clin Invest 119(8):2379-2387

237. Deak E, Jayakumar A, Cho KW, Goldsmith-Pestana K, Dondji B, Lambris JD, McMahon-Pratt D (2010) Murine visceral leishmaniasis: IgM and polyclonal B-cell activation lead to disease exacerbation. Eur J Immunol 40(5):1355-1368 
238. Wanasen N, Xin L, Soong L (2008) Pathogenic role of B cells and antibodies in murine Leishmania amazonensis infection. Int $\mathrm{J}$ Parasitol 38(3-4):417-429

239. Silva-Barrios S, Smans M, Duerr CU, Qureshi ST, Fritz JH, Descoteaux A, Stager S (2016) Innate immune B cell activation by Leishmania donovani exacerbates disease and mediates hypergammaglobulinemia. Cell Rep 15(11):2427-2437

240. Schaut RG, Lamb IM, Toepp AJ, Scott B, Mendes-Aguiar CO, Coutinho JF, Jeronimo SM, Wilson ME, Harty JT, Waldschmidt TJ, Petersen CA (2016) Regulatory IgDhi B cells suppress T cell function via IL-10 and PD-L1 during progressive visceral leishmaniasis. J Immunol 196(10):4100-4109

241. Buxbaum LU (2008) A detrimental role for IgG and FcgammaR in Leishmania mexicana infection. Immunol Res 42(1-3):197-209

242. Buxbaum LU, Scott P (2005) Interleukin 10- and Fcgamma receptor-deficient mice resolve Leishmania mexicana lesions. Infect Immun 73(4):2101-2108

243. Buxbaum LU (2013) Leishmania mexicana infection induces IgG to parasite surface glycoinositol phospholipids that can induce IL-10 in mice and humans. PLoS Negl Trop Dis 7(5):e2224

244. Nylen S, Akuffo H (2009) Tracing immunity to human leishmaniasis. Future Microbiol 4(2):241-254

245. Valli LC, Passos VM, Dietze R, Callahan HL, Berman JD, Grogl M (1999) Humoral immune responses among mucosal and cutaneous leishmaniasis patients caused by Leishmania braziliensis. $\mathbf{J}$ Parasitol 85(6):1076-1083

246. Anam K, Afrin F, Banerjee D, Pramanik N, Guha SK, Goswami RP, Gupta PN, Saha SK, Ali N (1999) Immunoglobulin subclass distribution and diagnostic value of Leishmania donovani antigenspecific immunoglobulin G3 in Indian kala-azar patients. Clin Diagn Lab Immunol 6(2):231-235

247. Ravindran R, Anam K, Bairagi BC, Saha B, Pramanik N, Guha SK, Goswami RP, Banerjee D, Ali N (2004) Characterization of immunoglobulin $\mathrm{G}$ and its subclass response to Indian kala-azar infection before and after chemotherapy. Infect Immun 72(2):863-870

248. Anam K, Afrin F, Banerjee D, Pramanik N, Guha SK, Goswami RP, Saha SK, Ali N (1999) Differential decline in Leishmania membrane antigen-specific immunoglobulin $\mathrm{G}(\mathrm{IgG}), \operatorname{IgM}$, IgE, and $\mathrm{IgG}$ subclass antibodies in Indian kala-azar patients after chemotherapy. Infect Immun 67(12):6663-6669

249. Marzouki S, Kammoun-Rebai W, Bettaieb J, Abdeladhim M, Hadj Kacem S, Abdelkader R, Gritli S, Chemkhi J, Aslan H, Kamhawi S, Ben Salah A, Louzir H, Valenzuela JG, Ben Ahmed M (2015) Validation of recombinant salivary protein PpSP32 as a suitable marker of human exposure to Phlebotomus papatasi, the vector of Leishmania major in Tunisia. PLoS Negl Trop Dis 9(9):e0003991

250. Vlkova M, Rohousova I, Drahota J, Stanneck D, Kruedewagen EM, Mencke N, Otranto D, Volf P (2011) Canine antibody response to Phlebotomus perniciosus bites negatively correlates with the risk of Leishmania infantum transmission. PLoS Negl Trop Dis 5(10): 1344

251. Abdeladhim M, Kamhawi S, Valenzuela JG (2014) What's behind a sand fly bite? The profound effect of sand fly saliva on host hemostasis, inflammation and immunity. Infect Genet Evol 28:691-703

252. Souza AP, Andrade BB, Aquino D, Entringer P, Miranda JC, Alcantara R, Ruiz D, Soto M, Teixeira CR, Valenzuela JG, de Oliveira CI, Brodskyn CI, Barral-Netto M, Barral A (2010) Using recombinant proteins from Lutzomyia longipalpis saliva to estimate human vector exposure in visceral leishmaniasis endemic areas. PLoS Negl Trop Dis 4(3):e649

253. Teixeira C, Gomes R, Collin N, Reynoso D, Jochim R, Oliveira F, Seitz A, Elnaiem DE, Caldas A, de Souza AP, Brodskyn CI, de Oliveira CI, Mendonca I, Costa CH, Volf P, Barral A, Kamhawi S, Valenzuela JG (2010) Discovery of markers of exposure specific to bites of Lutzomyia longipalpis, the vector of Leishmania infantum chagasi in Latin America. PLoS Negl Trop Dis 4(3):e638
254. Marzouki S, Abdeladhim M, Abdessalem CB, Oliveira F, Ferjani B, Gilmore D, Louzir H, Valenzuela JG, Ben Ahmed M (2012) Salivary antigen SP32 is the immunodominant target of the antibody response to Phlebotomus papatasi bites in humans. PLoS Negl Trop Dis 6(11):e1911

255. Drahota J, Martin-Martin I, Sumova P, Rohousova I, Jimenez M, Molina R, Volf P (2014) Recombinant antigens from Phlebotomus perniciosus saliva as markers of canine exposure to visceral leishmaniases vector. PLoS Negl Trop Dis 8(1):e2597

256. Kostalova T, Lestinova T, Sumova P, Vlkova M, Rohousova I, Berriatua E, Oliva G, Fiorentino E, Scalone A, Gramiccia M, Gradoni L, Volf P (2015) Canine antibodies against salivary recombinant proteins of Phlebotomus perniciosus: A longitudinal study in an endemic focus of canine leishmaniasis. PLoS Negl Trop Dis 9(6): 00003855

257. Alimohammadian MH, Hakimi H, Nikseresht M (1993) The preparation and evaluation of reference leishmanin from Leishmania major for use in man for diagnos tic and experimental purposes. Med J Islam Repub Iran 7(1):6

258. da Costa CA, de Toledo VP, enaro O, Williams P, Mayrink W (1996) Montenegro skin test-evaluation of the composition and stability of the antigen preparation. Mem Inst Oswaldo Cruz 91(2):193-194

259. Nylen S, Khamesipour A, Mohammadi A, Jafari-Shakib R, Eidsmo L, Noazin S, Modabber F, Akuffo H (2006) Surrogate markers of immunity to Leishmania major in leishmanin skin test negative individuals from an endemic area re-visited. Vaccine 24(47-48):6944-6954

260. Alimohammadian MH, Jones SL, Darabi H, Riazirad F, Ajdary S, Shabani A, Rezaee MA, Mohebali M, Hosseini Z, Modabber F (2012) Assessment of interferon-gamma levels and leishmanin skin test results in persons recovered for leishmaniasis. Am J Trop Med Hyg 87(1):70-75

261. Khamesipour A, Dowlati Y, Asilian A, Hashemi-Fesharki R, Javadi A, Noazin S, Modabber F (2005) Leishmanization: use of an old method for evaluation of candidate vaccines against leishmaniasis. Vaccine 23(28):3642-3648

262. Krolewiecki AJ, Almazan MC, Quipildor M, Juarez M, Gil JF, Espinosa M, Canabire M, Cajal SP (2017) Reappraisal of leishmanin skin test (LST) in the management of American cutaneous leishmaniasis: a retrospective analysis from a reference center in Argentina. PLoS Negl Trop Dis 11(10):e0005980

263. Follador I, Araujo C, Bacellar O, Araujo CB, Carvalho LP, Almeida RP, Carvalho EM (2002) Epidemiologic and immunologic findings for the subclinical form of Leishmania braziliensis infection. Clin Infect Dis 34(11):E54-58

264. Braz LMA (2019) Tegumentary leishmaniasis diagnosis: what happened with MST (Montenegro Skin Test) in Brazil? Rev Inst Med Trop Sao Paulo 61:e17

265. Skraba CM, de Mello TF, Pedroso RB, Ferreira EC, Demarchi IG, Aristides SM, Lonardoni MV, Silveira TG (2015) Evaluation of the reference value for the Montenegro skin test. Rev Soc Bras Med Trop 48(4):437-444

266. Sadeghian G, Ziaei H, Bidabadi LS, Nilforoushzadeh MA (2013) Evaluation of leishmanin skin test reaction in different variants of cutaneous leishmaniasis. Indian J Dermatol 58(3):239

267. Alvar J, Yactayo S, Bern C (2006) Leishmaniasis and poverty. Trends Parasitol 22(12):552-557

Publisher's Note Springer Nature remains neutral with regard to jurisdictional claims in published maps and institutional affiliations. 